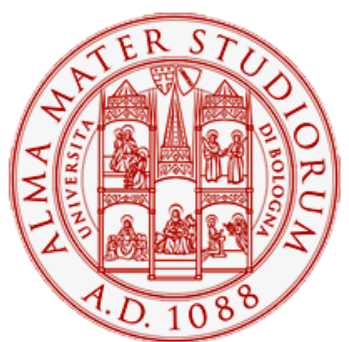

Alma Mater Studiorum - Università di Bologna DEPARTMENT OF ECONOMICS

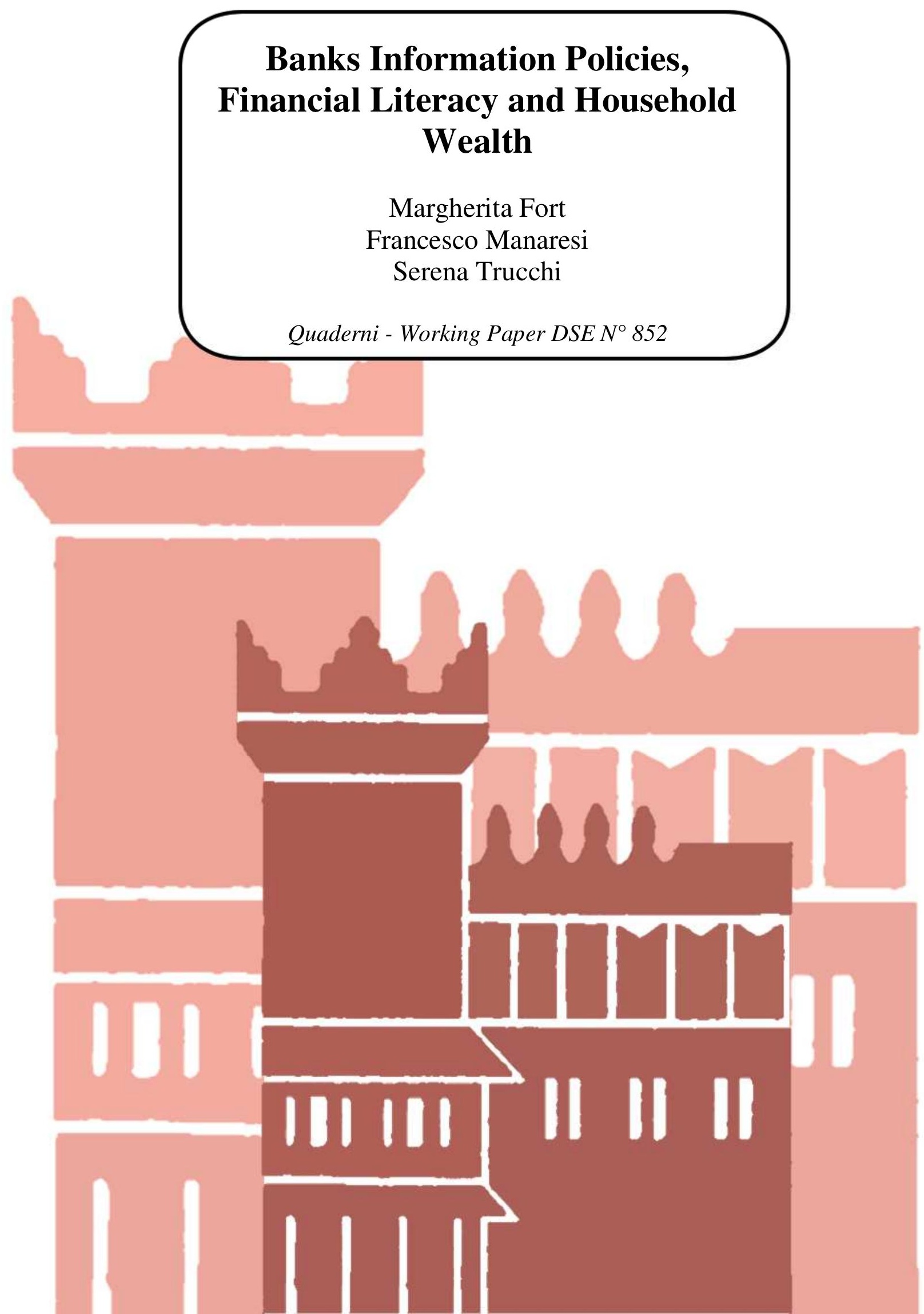




\title{
Banks Information Policies, Financial Literacy and Household Wealth *
}

\author{
Margherita Fort (University of Bologna, IZA, CHILD) \\ Francesco Manaresi (Bank of Italy) Serena Trucchi (University of Bologna, CeRP)
}

October 31, 2012

\begin{abstract}
We investigate the causal effect of financial literacy on financial assets, exploiting banks information policies for identification. In Italy, banks who belong to the PattiChiari consortium have implemented policies aimed at increasing transparency and procedural simplification. These policies may affect individuals' financial literacy without involving any direct cost for clients in terms of time, effort or resources, as we show in the paper. We exploit confidential information on whether individuals have their main bank account in one bank in the PattiChiari consortium to instrument their financial literacy level. We show that these policies have a positive and significant effect on both knowledge of financial instruments and household financial assets. Our results suggest that banks information policies have the potential to be an effective tool to increase individuals' financial literacy and that the relationship between financial literacy and wealth is largely underestimated by standard regression models.
\end{abstract}

Key words: Financial Literacy, Wealth, Instrumental Variables

JEL: D14, G11.

\footnotetext{
* Corresponding author: Margherita Fort , University of Bologna, Department of Economics; e-mail: margherita.fort@unibo.it. We acknowledge the financial support of MIUR- FIRB 2008 project RBFR089QQC-003J31J10000060001. We thank R. Bottazzi, M. Cervellati, M. Giofré, M. Hurd, M. Padula, E. Sette, and M. Wakefield and participants to the $2012 \mathrm{BoMoPaV}$ Economics Meeting, the 2012 Netspar International Pension Workshop, the 2012 SAVE-PHF Conference, the 2012 CERP Annual Conference on Financial Literacy, Saving and Retirement in an Ageing Society, the 2012 European Association of Labour Economists (EALE) Annual conference, and seminar at the University of Bologna for useful comments on an earlier version of this work. We thank the Bank of Italy Banking and Financial Supervision Area (notably, P. Franchini and A. Scognamiglio) for kindly providing data on bank account costs. We are indebted with the PattiChiari consortium (notably, V. Panna) for the data provided and for intriguing discussions about their initiatives. Margherita Fort is affiliated with IZA (Institute for the Study of Labor, Bonn) and CHILD (Centre for Household, Income, Labour and Demographic Economics). Serena Trucchi is affiliated with CeRP (Center for Research on Pensions and Welfare Policies). The views here expressed are those of the authors and do not necessarily reflect those of the Bank of Italy. The usual disclaimer applies.
} 


\section{Introduction}

The literature has recently emphasized the association between financial literacy or numerical and mathematical ability, on the one hand, and risk diversification, retirement savings, investment portfolios on the other. ${ }^{1}$ Both in Europe and in the US, there is evidence of low levels of financial literacy which is reflected into limited knowledge of economic concepts, like inflation or interest compounding (Jappelli, 2010). Lack of financial literacy and the mis-perception of crucial economic factors may lead individuals to make suboptimal investment choices and, thus, reduce individual wealth. ${ }^{2}$ In addition, errors in expectations of future resources may reflect into inadequacy of retirement savings (Bernheim, 1997; Hamermesh, 1984). Understanding the link between financial literacy and wealth is particularly important nowadays. Indeed, in the last decades, many European countries introduced reforms of the pension public provision system (e.g. increasing retirement age, shifting PAYGo to funded and changing the traditional defined-benefit (DB) contribution schemes into defined-contribution (DC) pensions). These reforms shift the burden of many decisions about financing retirement away from institutions toward individuals and thus determine a greater responsibility for workers in the accumulation of adequate retirement wealth.

The observed positive association between financial literacy and wealth may not be causal. The recent paper by Jappelli and Padula (2011) provides a theoretical study on the role of financial literacy extending the standard model of inter-temporal choices by including the choice of investing in financial literacy. According to their model, financial literacy is costly, in terms of both time and money expenditure, but allows consumers to access better investment opportunity and, thus, to increase the expected value of their investments' return. Jappelli and Padula (2011) stress that financial literacy is endogenous in the saving equation, an issue that has so far been almost neglected in the literature. ${ }^{3}$

The aim of the paper is twofold. First, we investigate the role played by financial institutions, like banks, in determining individual understanding of financial instruments. This may be significantly affected by the "information policy" of banks: for

\footnotetext{
${ }^{1}$ See for instance Bucher-Koenen and Lusardi (2011), Fornero and Monticone (2011), Guiso and Jappelli (2008), Lusardi and Mitchell (2007),van Rooij et al. (2011).

${ }^{2}$ See Fornero et al. (2011), Christelis and Padula (2010), van Rooij et al. (2011), Lusardi and Mitchell (2007).

${ }^{3}$ Exceptions are the recent papers by Disney and Gathergood (2011), van Rooij et al. (2011), Drexler and Schoar (2010), and Bucher-Koenen and Lusardi (2011).
} 
instance policies aimed at increasing transparency and procedural simplification may reduce the cost of acquiring financial information for the clients thereby improving their financial literacy. If banks engage in actions and establish rules aimed at increasing transparency and at simplifying the relationships with the client, the amount of financial literacy gained by the client will be higher without involving any direct cost for clients in terms of time, effort or resources. Second, we use the variation in financial literacy induced by banks' information policies to assess the causal effect of financial literacy on household financial assets.

To investigate the impact of banks' information policies on financial literacy we exploit a peculiar feature of the Italian banks' market. Since 2003, a large number of banks (around one hundred of them, corresponding to almost $75 \%$ of all national branches) implemented a self-regulation system called PattiChiari. This system is aimed at increasing transparency in the relationship with the client. Banks belonging to PattiChiari undertake several commitments in order to guarantee transparency and comparability of financial products and to offer simple tools to clearly understand sophisticated financial instruments. These commitments include providing information about mortgages and debts, and comparability of current accounts.

We use a nationally representative sample of Italian households (the Survey of Household Income and Wealth - SHIW, henceforth) for which we observe the bank where they hold their current accounts, the financial literacy of the household head, and the total financial assets. Financial literacy is measured with three questions regarding the knowledge of compound interest rates, inflation, and portfolio diversification. We use the information on whether household current main bank is a PattiChiari member to instrument the financial literacy of the household head.

We find that having a current account in a PattiChiari bank increases by 0.3 the number correct answers on financial literacy (about 16\% of the average number of correct answers) and we can rule out that our instrument is weak. We also look at the effect of our instrumental variable on household financial assets. Our results suggest that a being a PattiChiari client yields an increase of household financial assets of 4.900 euros (about $25 \%$ of average wealth observed in the sample).

Banks' information policies may provide a valid instrument for financial literacy in the saving equation if the two following assumptions are not violated. First, bank information policy must not affect consumers' choice of banks; second, banks belonging to the PattiChiari consortium must not differ systematically in elements that may 
affect wealth (apart from information policies). We are able to provide evidence on both assumptions.

Our results suggest that the relationship between financial literacy and wealth is largely underestimated by standard regression models. In addition, our findings point to large unintended consequences of banks' information policies on individuals' financial literacy. This channel did not receive much attention in the literature but may play a relevant role in shaping individual financial knowledge (and, thus, it may have an impact on household finances and welfare). From a policy perspective, bank's information policy may represent a cheap way to improve individual financial literacy among adults. Several institutions, such as the OECD, the U.S. Treasury Department and the Bank of Italy, have recently expressed the need for improved financial knowledge among European and US citizens, emphasizing the role of formal financial education in schools or at the workplace. Transparency and procedural simplification policies may represent complementary instruments that may foster the effectiveness of these educational interventions.

Finally, we can provide some preliminary evidence on the channels through which the effect takes place. More specifically, we investigate whether this relationship is due to a better ability to planning, i.e. if literate respondents are more prone to save and to save for retirement, or whether literate respondents are more prone to participate to the stock market. Our findings suggest that both these channels are relevant.

\section{Related Literature}

Our paper relates to the recent literature that studies the relationship between financial literacy and household wealth. In this brief review, we will restrict our attention to the papers most closely related to our contribution, namely those who acknowledge the potential endogeneity of financial literacy in the household wealth equation.

The recent paper by Jappelli and Padula (2011) provides a theoretical study on the role of financial literacy extending the standard model of inter-temporal choices by including the choice of investing in financial literacy. According to their model, financial literacy is costly, in terms of both time and money expenditure, but allows consumers to access better investment opportunity and, thus, to increase the expected value of their investments' return. They stress that financial literacy is endogenous in the saving equation, an issue that has so far received little attention in the literature. 
The same reasoning can be applied to other outcome variables, like wealth, stock market participation, planning for retirement, etc. For this reason, most recent papers have tried to develop an instrumental variable approach to elicit the causal effect of financial literacy on financial behavior of individuals and households. However, finding an exogenous source of variability in financial literacy is extremely complicated and most of the identification strategies adopted in observational studies so far are not free from criticism.

van Rooij et al. (2011) look at the relationship between financial literacy and wealth accumulation and use information on individuals' education in economics before labour market entry as an instrument for financial literacy. The authors' themselves are skeptical about the validity of the exclusion restriction for this instrumental variable and discuss the issue at length in the paper, adding a rich set of controls to their baseline specification. They find evidence of a strong positive association between financial literacy and wealth accumulation, particularly when focusing on what they call "advanced financial literacy" "and show that this association is neither affected by the inclusion of measures of individuals' confidence in their financial knowledge or their risk attitude -which conversely are important determinants of wealth accumulationnor by the inclusion of proxies for individuals' carefulness, propensity to save, individuals' self control nor by the inclusions of individuals' expectations of longevity, income uncertainty, household prices, replacement rate. With this strategy applied to data from the Netherlands, the authors' find IV estimates that are generally three times larger in magnitude that the OLS estimates. The results remain fairly similar when the authors use the financial knowledge of relatives (siblings and parents) as instruments for individual financial literacy. The idea underlying the choice of the instrumental variable is that individuals are influenced by their peers or reference group but cannot influence the peers' experience significantly. This assumes no 'reflection problem' (Manski, 1993).

Bucher-Koenen and Lusardi (2011), Fornero and Monticone (2011), Disney and Gathergood (2011) propose instrumental variable strategies similar to the one proposed by van Rooij et al. (2011), i.e. either using proxies or direct measures of financial knowledge of the relevant peer or reference group or using individual education in

\footnotetext{
${ }^{4}$ van Rooij et al. (2011)(p.15) "While the basic financial literacy index touches upon skills that individuals need on a daily basis, the advanced literacy index includes questions on the workings of stocks, bonds and mutual funds, which are complex concepts beyond what is needed to know to perform basic financial transactions".
} 
economics in the past. In their study on Germany, Bucher-Koenen and Lusardi (2011) consider exposure to financial knowledge of others in the same region or financial literacy of the parents. The authors do not measure financial knowledge of others in the same region directly but use a quite crude proxy, namely political attitudes at the regional level, relying on previous evidence by Kaustia and Torstila (2010) that suggest an important role for political attitude in financial decision making. They find evidence of a positive association between financial literacy and retirement planning ${ }^{5}$ and the magnitude of this is between three and thirteen times larger when they rely on the IV strategy, depending on the specification. ${ }^{6}$ Fornero and Monticone (2011) exploit information on whether individuals in the same household of the respondent have a degree in economics or use a computer as instrument for financial literacy in the equation for pension funds participation in Italy. Similar to previous studies, their results suggest that simple associations underestimate the marginal effect of financial literacy by six to ten times, depending on the specification. Disney and Gathergood (2011) investigate the relationship between financial literacy and net worth as well as consumer credit. The instrument they use for financial literacy is the share of time devoted to financial education whilst in full-time education, as a proxy of pre-labour market entry endowment in financial literacy. The OLS coefficient of financial literacy on wealth is biased downward, but it is very close to the IV coefficient.

A more convincing instrumental variable strategy is proposed by Lusardi and Mitchell (2011b). They take advantage of the fact that several US states mandated high school financial education in the past and exploit the exogenous variation in financial literacy induced by the exposure to the mandate to identify the effect of financial literacy on the propensity to plan for retirement in the US. Their results support previous evidence: the OLS estimate of the impact of financial literacy is biased downward and the marginal effect increases about five times using the IV strategies.

\footnotetext{
${ }^{5}$ Retirement planning captures whether respondents tried to find out how much they should save to reach a certain standard of living in retirement.

${ }^{6}$ Notice that the identification strategy relies on the idea that the political attitudes of sampled individuals are not affected by those of the population in the region. However, there are two arguments against this claim: first, from an economic point of view, social interactions in political attitudes may be present; second, from a statistical point of view, any (observed or unobserved) characteristic of the sampled individuals is an unbiased estimate of the regional mean of that characteristic. Hence, political attitudes measured at the regional level are a proxy of those of the sampled individuals. This strategy thus relies on the assumption that unobserved variables driving the endogeneity are averaged out once aggregated at the regional level, while they operate at the individual level. Whether this claim is true, is not obvious.
} 
This paper contributes to the literature by providing a new strategy (as discussed in more details in Section 4) to identify the causal effect of financial knowledge on financial assets, and by highlighting the role of information policies in fostering financial literacy.

\section{The PattiChiari consortium}

Since 2003, the Italian Banking Association (Associazione Bancaria Italiana: ABI, henceforth) has created the PattiChiari consortium. The aims of PattiChiari are twofold: to foster banking transparency and to enhance financial education of Italian households. For what regards the former, a bank that joins the consortium must introduce a set of tools (so called "Impegni per la qualità", i.e. "Quality Commitments") that refer to four areas: 1) information about mortgage and debt; 2) comparability of current accounts; 3) safety of home banking and payment cards; and 4) transferability of financial services across banks. ${ }^{7}$ Since 2010, a set of regulatory interventions have extended commitments 3) and 4) to all Italian banks, so that only the first two commitments are now peculiar of the consortium. Financial education has been fostered indirectly, by providing easy-to-read banking statements and extensive customer-care aimed at clarifying the functioning of financial tools and services, and directly, by promoting partnerships with trade associations and financial training initiatives at the local level in all areas where at least one PattiChiari bank is present. ${ }^{8}$

The number of banks that joined the consortium has increased overtime: currently 98 banks belong to it, corresponding to around $75 \%$ of all bank branches in the Italian territory. Figure 1 shows the distribution of the share of bank branches belonging to PattiChiari at the province level in 2006, 2008, and 2010. It is clear that the distribution of the share is not homogeneous over the territory. Notably, the NorthEastern regions of Trentino-Alto Adige, Friuli-Venezia Giulia, and Veneto have very

\footnotetext{
${ }^{7}$ More in details, the cost of closing a current account is fixed and known in advance by clients; costumers can switch to other banks and automatically transfer to the new bank information about financial investments, mortgages, loans and credits (transferability). Clients receive periodical statements about interest paid on mortgages (information about debts). Home banking and cash drawings are protected by double authentication systems; banks provide information about the cost of cash drawings and about the spread of cash dispenser (safety). Finally, comparability of the cost and the interest rate yielded by current accounts is guarantee by a search engine that provides the client with updated information (comparability). Optional commitments concerns provision of synthetic information when closing a current account and assistance to self-employed asking for a loan.

${ }^{8}$ Note, however, that direct interventions are typically targeted at young individuals enrolled in school at the time of the intervention while our analysis looks at household wealth of individuals who are already financially independent from the family of origin and typically not enrolled in school.
} 
few PattiChiari branches. This is mostly because of the diffusion of cooperative banks in those regions: no cooperative bank belongs to PattiChiari.

\section{Empirical Strategy}

We are interested in assessing the causal effect of financial literacy of the head of household $i$ at time $t$ in province $p\left(f l_{i p t}\right)$ on the financial assets of the same household at the same point in time and space $\left(w_{i p t}\right)$. The household head is defined as the household member who his responsible for economic and financial decision and is the only household member for which we observe financial literacy. Equation (1) below describes the empirical model we consider.

$$
w_{i p t}=\widetilde{\alpha}+\widetilde{\beta} f l_{i p t}+X_{i p t} \widetilde{\gamma}+\lambda_{p t}+\varepsilon_{i p t}
$$

$X_{i p t}$ is a vector of individual-level observable characteristics. We experimented with several subsets of these controls. ${ }^{9}$

Equation (1) allows for time specific province effects $\lambda_{p t}$ unobserved characteristics which may correlate with both financial literacy and the outcome variable. These regressors capture differences in the levels of financial literacy, wealth, and economic activity across provinces within Italy without restricting these factors to have a constant effect in different periods.

The existence of individual unobserved heterogeneity may still substantially bias the estimate of $\beta$. In addition, causal identification of the effect of financial literacy on wealth accumulation may be hampered by reverse causality: individual wealth may affect the incentive to increase financial education both through a change in the opportunity-cost of time and through a change in the relative benefit from knowing how financial tools work.

With panel data, one could consider including individual fixed effect in equation (1). There are three main arguments that prevent the use of individual fixed effects to address these issues. First, both financial assets and financial literacy are highly stable over the restricted sample period in which we observed them. Second, respondents can learn from previous interviews. Thus, the variation in the number of correct answers

\footnotetext{
${ }^{9}$ In the baseline specification $X_{i p t}$ includes gender of the household head, a second-order polynomial in age, household size, marital status, size of the municipality (3 categories: 20,000-40,000; 40,000500,000 ; more than 500,000 inhabitants). The inclusion of other covariates is discussed in Section 5.
} 
for those who are interviewed more than once may capture learning of specific answers, instead of the overall level of financial literacy. ${ }^{10}$ Third, using the longitudinal sample would reduce sample size because of attrition.

To solve both omitted variable and reverse causality issues, we pursue an instrumental variable approach. We use information about whether the household's bank account is in a PattiChiari bank or not to predict the actual level of financial literacy of the household head. In the baseline model, we consider only the main bank account (as identified by the household), among the robustness checks we will consider even other bank accounts owned by the household. We control for possibly endogenous changes in the availability of PattiChiari branches over the Italian territory by focusing on intra-provincial (and even intra-municipal; see results in the robustness checks section) variability among households who are clients of a PattiChiari bank.

The first-stage equation corresponding to the model in equation (1) is presented in equation (2).

$$
f l_{i p t}=\widetilde{\alpha}_{0}+\widetilde{\alpha}_{1} p c_{i p t}+X_{i p t} \widetilde{\alpha}_{2}+\lambda_{p t}+\widetilde{\nu}_{i p t}
$$

where our instrumental variable $p c_{i p t}$ is a dummy equal to 1 if the main current account owned by the household is in a bank belonging to the PattiChiari consortium and the other included regressors coincide with those considered in equation (1). ${ }^{11}$

Our strategy relies on two identification hypotheses. First, banks belonging to the PattiChiari consortium must not be systematically different with respect to banks that do not belong to it in any characteristics (apart from information policies) that may affect household wealth. Second, individuals must not self-select as clients of a specific bank according to the bank information policy but rather depending on other relevant variables - such as the distance between the bank and their residence - which do not directly affect their financial literacy or wealth, conditional on province of residence, in any specific time-period. If clients choose their banks based on different criteria (like distance from home or advertisements $)^{12}$ and affiliation to PattiChiari is not correlated

\footnotetext{
${ }^{10}$ See Section 5 for a discussion of the relevance of this channel.

${ }^{11}$ Among the robustness checks we considered different definitions of the instruments, such as whether all or at least one of the current accounts are in PattiChiari banks. Results discussed in Section 6 are robust to these different choices.

${ }^{12}$ The location is shown to be the most important criterion in bank selection decision (Dupuy and Kehoe, 1976; Phuong Ta and Yin Har, 2000).
} 
with any confounding factor that may directly affect wealth, then information policies might induce exogenous changes in individual financial literacy.

These two assumptions are only partly testable on the basis of the data at our hands, but they deserve a careful discussion. We first provide complementary evidence showing that: a) PattiChiari and non-PattiChiari banks do not differ with respect to policies that may affect household wealth accumulation ${ }^{13}$ in a way that explains our results; b) cost and information policies are not the main reasons for choosing a bank.

We collected information from a nationally representative sample of bank accounts, administered by the Bank of Italy's Banking and Financial Supervision Area. Among the 8233 bank accounts surveyed, we distinguish those belonging and not belonging to a PattiChiari bank. Descriptive statistics on costs charged by the two categories of banks are reported in Table 1, together with a Welch test on equality between means of the two groups. The variables analysed describe heterogeneity in fees charged on bank clients and, in addition, may reflect structural differences in policies implemented by different types of bank. Basic fees for bank accounts as well as average cost of bank transfers for clients of PattiChiari banks are usually significantly higher than those charged to the clients of non-PattiChiari banks. Conversely, the yearly fees charged for Bancomat and credit cards are statistically lower for clients of PattiChiari banks. Albeit statistically significant, all these differences between PattiChiari and non- PattiChiari banks are in general rather small ranging between nearly four euros per year charge increase for basic account services to a two euro reduction in the fee for debit and credit card. Note that considering only fixed fees (column 1 to 3 in Table 1) the differences would sum to zero. All in all, it is unlikely for these differences to be the main driver of our results and there is no evidence of structural differences in policies implemented by PattiChiari and non-PattiChiari banks.

In addition, banks that belong to the PattiChiari consortium may differ from the other banks with respect to credit rationing and mortgage policies that, in turn, affect household wealth through the cost of debit. To check whether PattiChiari and non-PattiChiari banks systematically differ with respect to credit policies, we rely on information about liquidity constraints and mortgage provided by SHIW. ${ }^{14}$ The first column of Table 2 reports the correlation between the PattiChiari dummy and the

\footnotetext{
${ }^{13}$ We consider the annual price for bank accounts and fees charged to banking operations, the availability of credit or the interest rate charged on loans.

${ }^{14} \mathrm{~A}$ caveat is due to the fact that this information reflects the equilibrium between supply and demand.
} 
probability that the respondents is liquidity constrained, which may signal differences in credit rationing. Following Jappelli et al. (1998), we consider liquidity constrained those households that either: a) applied to a bank or a financial company to ask for a loan or a mortgage and the application was rejected; or b) answer positively to the following question "In [year] did you or any other member of your household consider the possibility of applying to a bank or a financial company for a loan or a mortgage but then change your mind thinking that the application would be rejected?". We do not find evidence of any correlation between being PattiChiari client and being liquidity constrained (see Table 2) at standard significance levels. To investigate the existence of differences in credit policies between PattiChiari and non-PattiChiari banks we focus on a particular type of credit, i.e the mortgage for the purchase of the dwelling. The second column of Table 2 reports estimate results for the probability of having a fixed-rate-mortgage (FRM) vis-à-vis an adjustable-rate-mortgage (ARM), while the third and fourth columns shows the correlation between the PattiChiari dummy and the interest rate level for FRM (third column) and ARM (last column). The coefficient associated to the variable "Client of PattiChiari" is not significant in any regression of Table 2 .

Figure 2 supports the validity of the second assumption, i.e. that cost and information policies are not important reasons for choosing a bank. It plots the distribution of household's reasons for choosing the main bank: convenience, economic reasons, type of bank. ${ }^{15}$ We distinguish between clients of a PattiChiari/non-PattiChiari bank (upper panel) and between households who changed their bank/remained client of the same bank in the last two years (lower panel). ${ }^{16}$ By large, the main reason for choosing a bank is related to convenience, that is the only determinant for $63 \%$ of PattiChiari clients and for $67 \%$ of other respondents, while financial conditions are the only determinant for less than $15 \%$ of the respondents in each subgroup. If anything, financial

\footnotetext{
${ }^{15}$ More in details, the respondent is asked the question "Why did you choose [the bank you use more often] when you and your household first began using it?" and can give at most two answers choosen between 13 alternatives. We these alternatives into three broad groups - i.e. convenience (convenience to home/work, respondent's employer's bank (or respondent's business's bank)), financial/economic reasons (favourable interest rates, speed of transaction execution, range of services, low fees for services, possibility of online banking) and bank type (it is a well-known, important bank, staff courtesy). The figure plots the percentage of respondents who choose only one alternative, two alternatives in the same group or two alternatives in different categories.

${ }^{16}$ More in details, we isolate four types of clients: clients who changed their main bank, either moving to a PattiChiari bank (to $P C$ ) or to another bank (to non-PC), and households who remain clients of a bank that belongs (No switch $(P C)$ ) or not (No switch (non PC)) to the PattiChiari consortium.
} 
conditions are valued more by clients of banks that are not in the consortium. Similar patterns are observed across the four categories in the lower panel, where financial conditions are choosen more often by clients who remain clients or move to a PattiChiari bank. Table 3 show the results of the conditional correlation between the reason for choosing a bank and the probability of being client of a bank that belong to the PattiChiari consortium (probit estimate). In the first column we include as regressors dummies for the 9 categories; in the second and the third one we use two dummies that capture, respectively, if the respondent picks only financial reasons or at least one financial reason. The table shows a correlation between the determinants of bank's choice and the probability of using a PattiChiari bank, but, in line with bivariate correlation, clients of PattiChiari banks value less economic condition and bank's product supply. This channel is, thus, unlikely to determine a positive correlation between wealth and the instrument. To further address this potential issue, in addition, we will control for the reasons for choosing the bank in the empirical analysis: as we will discuss more in details in Section 5, we cannot reject the assumption that they are significant in the financial assets equation, but they do not affect the significance and the magnitude of other coefficients, in particular the IV results -notably the first stage and ITT- are unaffected by the inclusion of these controls, while precision of the estimates is improved.

Exclusion restrictions are violated if the commitments taken by PattiChiari branches (see section 3) affect the returns to financial investment because they contribute to decrease the risk of investments. Since clients have to choose or agree upon a proposed portfolio allocation and PattiChiari branches cannot influence the real risk of a particular asset available on the market, we view this as an indirect effect of PattiChiari that only operates through its effect on individuals' financial literacy rather than directly.

PattiChiari and non-PattiChiari banks may also differ in the ability to segment the supply of financial products. If PattiChiari banks are more able to discriminate customers, they may charge worse financial conditions to illiterate clients. In this case, the PattiChiari variable, may not capture the impact of information policies but the effect of higher asset returns (or, equivalently, lower cost of borrowing or buying financial products). This may be an issue if PattiChiari and nonPattiChiari banks also differ with respect to unobservables that are correlated with the ability to discriminate ("relational" Vs "market oriented" model). Assuming that this difference 
is stable within province (and eventually varies overtime), we can account for this within our framework.

Finally, we exploit panel data to construct a set of instruments (based on the information of individuals who 'switch' between banks in or our the PattiChiari consortium) and perform an overidentification test (computing the Hansen J statistics) for the exogeneity of our instrument (see Section 6). We find evidence supporting the exogeneity of our instrument (i.e. being client of a PattiChiari bank) in the financial assets equation.

\subsection{Data}

We use data from the Italian Survey on Household Income and Wealth (SHIW), a biannual survey that collects a large set of information concerning household income, savings, financial portfolios, and wealth from a nationally representative sample of Italian households. The empirical analysis relies on the 2010 wave. ${ }^{17}$

The 2010 wave includes specific questions to measure the financial literacy of the household head. They relate to basic financial literacy concepts, like portfolio diversification, the risk associated to fixed or adjustable interest rate and the effect of inflation. ${ }^{18}$ We measure financial literacy with the number of questions that the household head answered correctly. Table 4 shows that almost three out of four respondents answered correctly to the question on inflation; the percentage of correct answers to

\footnotetext{
${ }^{17}$ Baseline analysis are based on the 2010 wave, since questions about the reasons for choosing the bank are available only in this year. In Section 6 , we check the validity of the results in a larger sample, that also includes 2006 and 2008 waves (questions about financial literacy were not asked before): results are qualitatively and quantitatively consistent.

${ }^{18}$ The first and the third one are similar to the ones devised for the US Health and Retirement Study (Lusardi and Mitchell, 2011a) while the second one is not included in the HRS. Specifically, the three questions used in the analysis are:
}

- Understanding inflation. Imagine leaving 1,000 euros in a current account that pays $1 \%$ interest and has no charges. Imagine also that inflation is running at $2 \%$. Do you think that if you withdraw the money in a year's time you will be able to buy the same amount of goods as if you spent the 1,000 euros today? Yes/No, I will be able to buy less (correct answer)/No, I will be able to buy more/Do not know

- Understanding mortgages. Which of the following types of mortgage do you think will allow you from the very start to fix the maximum amount and number of installments to be paid before the debt is extinguished? Floating rate mortgage/Fixed rate mortgage (correct answer)/Floating rate mortgage with fixed installments/Do not know

- Portfolio diversification. Which of the following investment strategies do you think entails the greatest risk of losing your capital? Investing in the shares of a single company (correct answer) / Investing in the shares of more than one company/Do not know/No answer 
the question on mortgages is $64 \%$; the question on portfolio diversification has been answered correctly by $55 \%$ of the household heads. On average respondents answered correctly to less than two questions, and one respondent out of three correctly answered to all questions.

Household financial assets is elicited by the SHIW questionnaire. It is defined as the sum of deposits, securities, and commercial credits.

The Italian Bank Association (ABI) has provided us with the date of entrance and exit of each Italian banking group in the PattiChiari consortium. We use this information, together with the answer to questions about the banks used by the household, to build a variable that capture whether the household is client of a bank that is part of the PattiChiari consortium. Our baseline analysis rely on a dummy $(p c)$ that is equal to one if the main bank used by the respondent belong to the consortium and zero if it does not: $73 \%$ of respondents in our sample are clients of a bank that belongs to PattiChiari consortium (Table 4). Alternatively, in the robustness section, we consider different definitions of this dummy: pc_nobnk includes among non-PattiChiari clients those households that do not have any bank account; variables pc_all and pc_atleast are equal to 1 if, respectively, all bank accounts and at least one bank account are in a PattiChiari bank.

The unit of analysis is the household. After excluding from our sample outliers (the upper and lower $5 \%$ tails of the financial assets distribution) and respondents who do not report the reason for choosing the bank, the final sample size is 4972 observations (descriptive statistics are shown in Table 4).

\section{$5 \quad$ Findings}

In this section, we present our baseline results.

First, we discuss estimates of the effect of having the main current account in a PattiChiari bank on financial literacy (the First-Stage effect) and financial assets accumulation (corresponding to the Intention-To-Treat effect). These estimates are interesting per se since they document potentially unintended consequences of bank's information policies. Second, we combine these estimates to assess the effect of financial literacy on financial assets accumulation.

Table 5 and 6 show estimated effect of financial literacy on financial assets controlling and not controlling for motivations for choosing the bank. Tables report the 
estimates of the association between assets and financial literacy (OLS column), the causal effect of having a current account in a PattiChiari bank on financial assets (ITT column) and financial literacy (FS column) and the causal effect of financial literacy on financial assets (IV column). In all the following regressions, estimated standard errors are robust to both heteroskedasticity and serial correlation at the province level, the largest level at which we have enough clusters (103) to obtain consistent estimates of the second moment of the parameters (Moulton, 1990). The inspection of the two tables shows that the inclusion of motivations among the regressors do not alter significantly the point estimates of the PattiChiari dummy and of the key variables of interest.

Our comments are based on results reported in Table 6, that is our preferred specification. The association between financial literacy and financial assets is positive: our estimates suggest that one more correct answer is associated with an increase in financial assets by almost 4 thousand euros. As discussed in Section 4 , this estimate is unlikely to reflect a causal relationship but represent an important benchmark for our analysis. Notably, the strength of the association we measure is very similar to those found in previous studies, albeit the measure of financial literacy used here and by other authors differs.

We now turn to the analysis of the link between banks' information policies, financial literacy and financial assets. The second column (FS) reports the estimate of the effect of having the main bank account in PattiChiari bank on financial literacy: the instrument is not weak (the F-test on excluded instruments is 58) and positively correlated with the financial literacy. The point estimate suggests that being a client of a PattiChiari bank has the potential to allow one individual to give 0.3 additional correct answers $(+15 \%$ with respect to the average number of correct answers given in the sample).

The third column (ITT) reports the coefficient of the dummy signaling that the household has its main current account in a PattiChiari bank in the financial assets equation. As long as the exclusion restriction of the instrument holds, this coefficient can be considered an unbiased estimate of the intention-to-treat (ITT) effect. The effect is positive and significant: having the main current account in a PattiChiari bank raises household financial assets by about 5 thousand euros, roughly one fourth of the average value of assets in our sample. Other regressors have the expected sign 
(Table 6): financial assets are increasing and concave in age and household size and they are greater for married couples and households with male household head.

In each specification, the fourth column (IV) provides the 2SLS estimates of the effect of financial literacy on financial assets. The estimates are larger that what simple association suggests. On average, one additional correct answer provided, conditional on other covariates, leads to an increase of household assets of 17 thousand euros; the corresponding association is generally around 4 times lower. These results are in line with previous empirical analyses. van Rooij et al. (2011) show that the IV estimate of the effect of financial literacy on wealth is almost three times that predicted by the OLS, while our findings show the marginal effect estimated by IV to be much almost 5 times larger with respect to the OLS one.

A final note for the results on the motivations given for choosing the bank where the household has its current account. Apart from the spurious OLS correlations, the results signal that individuals choosing a bank for its service have in general a higher financial literacy. This result is somehow straightforward (those who are more financially literate value financial services more), and must be related with the results of Table 3 showing that are on average respondents who choose a bank for its financial services are less likely to be PattiChiari client. If anything, this possible selection effect should bias our first stage estimate of being a PattiChiari client downwardly.

\section{Robustness and Extensions}

We now test the robustness of our findings to several alternative definitions of the sample and alternative measures of our key regressors (financial literacy, and being a PattiChiari bank client) and provide some extensions to our analysis.

As discussed in Section 4, our identification strategy is based on the assumption that the choice of the bank is not correlated with factors that may affect wealth. Georgarakos and Inderst (2011) find that the level of trust in institution and financial advisors may affect individual investment decision and, thus, their wealth. If respondents with a higher level of trust are also more likely to choose a bank in the PattiChiari consortium because of its commitments to transparency and clarity, the coefficients in the previous tables may be upwardly biased. To check whether this is the case in our sample, we include proxies for trust among the controls. We exploit two different sources of information: survey respondents in SHIW are interviewed about trust in 
their main bank and about the length of the relationship with their main bank. We exploit answers to each of these questions in turn, in our analysis. In the first panel of Table 7 we add a dummy that captures whether the respondent trusts his/her main bank. ${ }^{19}$ The table shows that trust is not significant and the results are similar to the baseline specification. In the second panel of Table 7 we control for the length of the relationship between the client and the bank: we expect a longer relationship to reflect higher trust in the bank. This variable increases the level of financial assets (ITT and IV) but does not significantly affect financial literacy; the effect of financial knowledge and of the instrument are not sensible to the inclusion of either of these additional controls.

We also run the regressions controlling for the education level of the household head (years of education): results are reported in the third panel of Table 7 . We find evidence of a non-trivial interaction between financial literacy and education. ${ }^{20}$ When we control for education, the effect of being a PattiChiari client on financial literacy remains relatively stable with respect to the baseline specification ${ }^{21}$, while the effect of our instrument on the level of financial assets is reduced by nearly $44 \%$. Our qualitative findings on the causal effect of financial literacy on financial assets are confirmed also in this case, but the resulting magnitude of the effect is smaller (by nearly $27 \%$ ) since the instrumental variable estimate moves from about 16.7 to 12.2 thousand euros. These results have to be interpreted with caution because also education may be endogenous in the wealth equation and we do not address this endogeneity problem here.

We checked the robustness of our findings to different measures of financial literacy. First, we define a dummy equal to 1 if all three questions have been answered correctly. Second, we consider each question separately. Results reported in Table 8 show that being a PattiChiari client is strongly correlated with all these definitions, and the causal effect is found to be highly significant and positive in all four cases. In addition, we considered alternative different measures of the instrumental variable as well: we included households not having any current accounts as part of the control group, and we created dummies equal to 1 if all or at least one current account belong to a

\footnotetext{
${ }^{19}$ The dummy is equal to one if the answer is above the median ( 8 in a scale between 0 and 10). Similar results are obtained if we set it equal to one if the answer is above 5.

${ }^{20}$ The education level of the household head affects financial literacy in the first stage equation

${ }^{21}$ The first stage effect changes from 0.296 to 0.229 .
} 
PattiChiari bank. Results are qualitatively similar to our baseline specification (see Table 9$).{ }^{22}$

A possible concern refers to the timing of the effect of the treatment (i.e. being client of a bank that belongs to the consortium). To address the robustness of the results to this issue, we exploit the panel component of the sample and we estimate the effect of being exposed to bank information policy in 2008 or in 2006. Results confirm our main findings (see Table A-2 in the Appendix).

Previous specifications are robust to the existence of province fixed effect. But municipality-specific factors may drive both the level of wealth and the probability of being client of a PattiChiari bank (e.g. if different banks decide to open branches in particular type of municipality). We include municipality-fixed effects and replicate our baseline results: previous findings are confirmed (see Table A-1 in the Appendix).

The year 2010 may not be a representative year to assess the role of financial literacy. Indeed, during the crisis (as the financial market shrinks and banks reduce markedly their credit to firms and households) having knowledge of financial instruments may represent a stronger advantage with respect to what happens during normal years. Questions concerning financial literacy are included in the SHIW since the 2006 wave. However, unfortunately only 2 questions are common to all three waves (2006, 2008, and 2010): the one regarding knowledge of inflation mechanism and the one on different types of loan repayment schemes. We restrict our analysis to these 2 questions and estimate our baseline model, including a set of year fixed effects. Results are shown in table 10 and confirm previous findings. In the SHIW dataset there is a rotating panel subsample: the specification in the upper panel of table 10 includes these household several times, as they are interviewed more than once over the three waves. These households, may, however learn the questions from one interview to the other, and thus tend to be more likely to answer correctly overtime. At the same time attrition in the panel subsample tends to be higher among worse-off households (see Biagi et al. (2009)). The results of both learning and non-random attrition may upwardly bias our estimate of the effect of financial literacy. We, then, include in the sample only the first interview made by each households. The comparison between this and the previous regressions shows that learning has a significant effect: including the first

\footnotetext{
${ }^{22}$ We look at various dimensions of heterogeneity, and estimate our baseline model on different subsamples (see Tables A-3,A-4,A-5 in the Appendix). We find that the impact of financial literacy is slightly larger for households living in a large city, in northern Italy and where the household head is a male.
} 
interview only raises the impact of financial literacy on financial assets by 8 thousand euros. $^{23}$

In addition, we can exploit the panel dimension to expand the set of instruments and perform and overidentification test of the exclusion restriction of our IV approach. In order to do so, we focus on those households that are sampled both in 2008 and in 2010 and we distinguish four groups among them: those that have remained clients of PattiChiari over the two years, those that have remained clients of a non-PattiChiari bank, and two groups of 'switchers', i.e., those that have moved from a PattiChiari to a non-PattiChiari bank, and vice-versa. The four groups identify three instrumental variables (plus a baseline group). All these variables can be used to predict financial literacy in 2010. Results are summarized in the first panel of Table 11. The firststage shows that there are no significant differences in financial literacy between those who were clients of PattiChiari since 2008 and remained in this status (the omitted baseline) and those who switched to a PattiChiari bank during the 2008-2010 period. Conversely, financial literacy is smaller among those who are not clients of PattiChiari in 2010. This negative effect is smaller for those who switched to a non-PattiChiari bank between the two waves of the SHIW with respect to those who were not PattiChiari clients in 2008. Turning to the ITT estimate, there is a significant difference in financial assets only between those who did not switch over the 2008-2010 period: households that remained non-PattiChiari clients have on average almost 7 thousands euro less with respect to those who remained PattiChiari clients. The IV estimate of the effect of financial literacy on financial assets is particularly strong: an additional correct answer increases financial assets by 31 thousands euros. The Hansen J test does not reject the null hypothesis of exogeneity of the instruments with a fairly high p-value (0.22). The lower panel of table 11 replicates the exercise focusing on bank-switchers over the 2006-2010 period (two waves). Although the sample size is almost halved, the Hansen J test yields a very high p-value (0.91). The IV estimate of the causal effect of financial literacy on financial assets is reduced by one third with respect to the previous estimate: an increase in financial literacy induces a raise of 20 thousands euros in financial assets.

\footnotetext{
${ }^{23}$ Recall that: i) the magnitude of the effect is different from the baseline regression because financial literacy is defined used a different number of questions (2 instead of 3 ); ii) the same respondents belong to the samples in the upper and lower panel.
} 
Finally, we turn to the analysis of the channels that drive the positive effect measured in the aggregate. We identify three potentially relevant mechanisms that may explain it: literate respondents may save more (e.g., for retirement), may be more prone to plan for retirement and, finally, may hold a better-diversified portfolio. ${ }^{24}$ Table 12 reports the estimate of association (OLS), FS, ITT and IV for the three outcomes. All the channels seem to be relevant in explaining our findings: answering correctly to one more questions increases saving by more than 6 thousand euros per year and increases the likelihood of planning for retirement by 0.27 (roughly $60 \%$ of the sample mean). The marginal effect of financial literacy on the probability of investing, directly or indirectly, in the stock market is almost $20 \%$ (above the sample mean).

\section{Concluding remarks}

The interests by scholars and policy-makers in Europe and in the US on the determinants of financial literacy and on the link between financial literacy and savings has been constantly increasing in the last years and some institutions, such as the OECD, the U.S. Treasury Department and the Bank of Italy, have expressed the need for improved financial knowledge among European and US citizens, emphasizing the role of formal financial education in schools or at the workplace.

This research contributes to the investigation of these issues introducing a new and possibly complementary policy instrument. We start from recognizing the role of banks information policies as determinant of individuals' levels of financial literacy. This channel did not receive much attention in the literature but may play a relevant role in shaping individual financial knowledge and, thus, it may have impact on household finances and welfare.

We identify a group of Italian banks that implement active policies aimed at increasing transparency. These are the members of PattiChiari, a banking self-regulation system that includes around one hundred banks (almost $75 \%$ of total Italian branches), that are not uniformly distributed across Italian regions. These banks undertake several commitments in order to guarantee transparency and comparability of financial products and to offer clients simple tools to clearly understand sophisticated financial

\footnotetext{
${ }^{24}$ We exploit, respectively, information about savings, the answer to the questions "Have you ever thought about how to arrange for your household's support when you retire?" (not asked to retiree), and information on asset held (the dummy is one if the respondent own stocks or a mutual funds).
} 
instruments but do not offer services at lower costs with respect to banks outside the consortium.

We exploit the SHIW dataset, a survey that provides information on the bank where the household has its current account and on the household head's financial literacy, to assess the impact of bank information policies on individual financial knowledge. We find that being client of a PattiChiari bank translates into a 0.3 percentage points increase in financial literacy. We also look at the effect of our instrumental variable on household financial assets and on various components of it. Results based on our identification strategy suggest that being client of PattiChiari yields an increase of household financial assets of around 5 thousand euros. We can rule out that these effects are driven by differences in the cost of financial services between PattiChiari banks and banks not in the network.

We then use the variation in financial literacy induced by banks information policies to assess the role of financial information processing in determining household wealth. If, conditional on province of residence, individuals self-select into banks not according to their information policies but rather depending on other relevant variables, such as the distance between the bank and their residence -as done most frequently in our sample-, bank's information policies may provide a valid instrument for financial literacy in the saving equation and thus allow us to assess the causal effect of financial knowledge on wealth and portfolio composition accounting for endogeneity. Our results suggest that the relationship between financial literacy and financial assets is largely underestimated by OLS regressions.

We investigate the channels through which financial literacy increases financial assets and we show that literate households save more, are more prone to plan for retirement and are more likely to participate, directly or indirectly, to the stock market.

Our findings have relevant policy implications: first, they suggest alternative ways to improve individuals financial knowledge with respect to formal education in schools on at the workplace; second, they suggest that the association between financial knowledge and wealth largely underestimates the true causal effect. In addition, we highlight some of the channels through which this positive effect may take place: we find that higher financial literacy leads to higher savings, increases in the probability of planning for retirement and higher participation to the stock market. 


\section{References}

Bernheim, B. D., 1997. The Adequacy of Personal Retirement Saving: Issues and Options. Stanford, CA: Hoover Institution Press.

Biagi, F., Giraldo, A., Rettore, E., 2009. Gli effetti dell'attrito sulla stima della disuguaglianza in italia. In: Brandolini A., C. Saraceno, A. S. (Ed.), Dimensioni della disuguaglianza in Italia: povert $\tilde{A}$, salute, abitazione. Il Mulino.

Bucher-Koenen, T., Lusardi, A., 2011. Financial Literacy and Retirement Planning in Germany. Journal of Pension Economics and Finance 10 (4).

Christelis, D., J. T., Padula, M., 2010. Cognitive Abilities and Portfolio Choice. European Economic Review 54 (1).

Disney, R., Gathergood, J., 2011. Financial literacy and indebtedness: New evidence for uk consumers. SSRN Household Finance e-Journal 2 (75).

Drexler, A. F. G., Schoar, A., 2010. Keeping it simple: Financial literacy and rules of thumb. Working Paper DP7994, CEPR.

Dupuy, G. M., Kehoe, W. S., 1976. Comments on Bank Selection Decision and Marketing Segmentation. Journal of Marketing 9 (4).

Fornero, E., Monticone, C., 2011. Financial Literacy and Pension Plan Participation in Italy. Journal of Pension Economics and Finance 10 (4).

Fornero, E., Monticone, C., Trucchi, S., 2011. The Effect of Financial Literacy on Mortgage Choices. Discussion Paper 09/2011-085, Netspar.

Georgarakos, D., Inderst, R., 2011. Financial advice and stock market participation. Working paper.

Guiso, L., Jappelli, T., 2008. Financial Literacy and Portfolio Diversification. Working Paper 2008/31, European University Institute.

Hamermesh, D. S., 1984. Consumption During Retirement: the Missing Link in the Life Cycle. The Review of Economics and Statistics 66 (1), 1-7.

Jappelli, T., 2010. Economic Literacy: An International Comparison. The Economic Journal 120 (548). 
Jappelli, T., Padula, M., 2011. Investment in Financial Literacy and Saving Decisions. Working Paper No. 272, CSEF.

Jappelli, T., Pischke, J., Souleles, N., 1998. Testing for liquidity constraints in Euler equations with complementary data sources. Review of Economics and Statistics $80(2)$.

Kaustia, M., Torstila, S., 2010. Stock Market Aversion? Political Preferences and Stock Market Participation. Discussion paper, Aalto University.

Lusardi, A., Mitchell, O. S., 2007. Financial Literacy and Retirement Preparedness: Evidence and Implications for Financial Education. Business Economics 42 (1).

Lusardi, A., Mitchell, O. S., 2011a. Financial literacy and planning: Implications for retirement wellbeing. In: Lusardi, A., Mitchell, O. S. (Eds.), Financial literacy: Implications for Retirement Security and the Financial Marketplace. Oxford: Oxford University Press.

Lusardi, A., Mitchell, O. S., 2011b. Financial literacy and retirement planning in the united states. Journal of Pension Economics and Finance 10 (04).

Manski, C., 1993. Identification of Endogenous Social Effects: the Reflection Problem. The Review of Economic Studies 60 (3), 531-542.

Moulton, B., 1990. An Illustration of a Pitfall in Estimating the Effects of Aggregate Variables on Micro Units. Review of Economics and Statistics, 334-338.

Phuong Ta, H., Yin Har, H., 2000. A Study of Bank Selection Decisions in Singapore Using the Analytical Hierarchy Process. International Journal of Bank Marketing.

van Rooij, M., Lusardi, A., Alessie, R., 2011. Financial Literacy, Retirement Planning, and Household Wealth. Economic Journal. 
8 Figures 


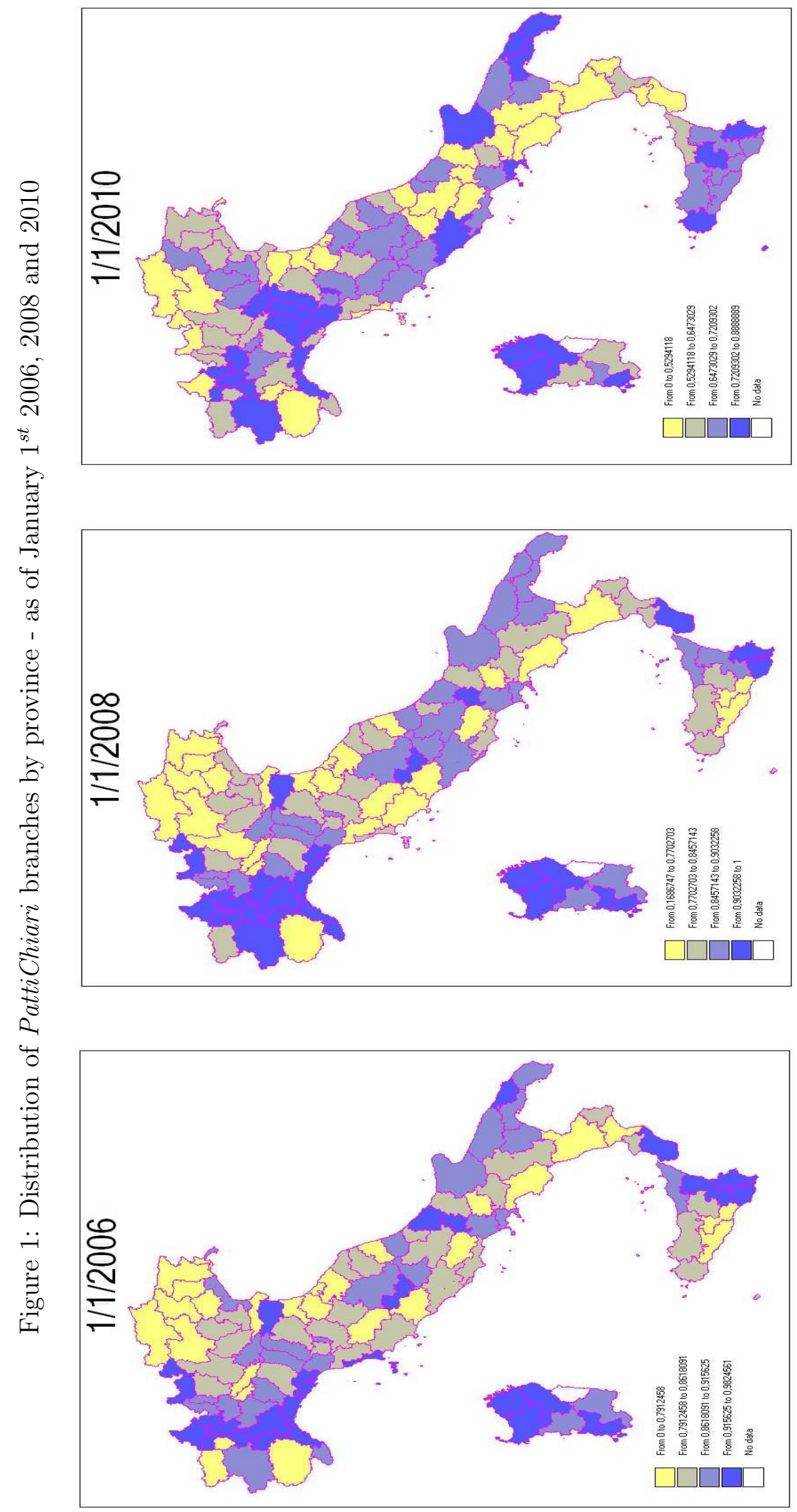




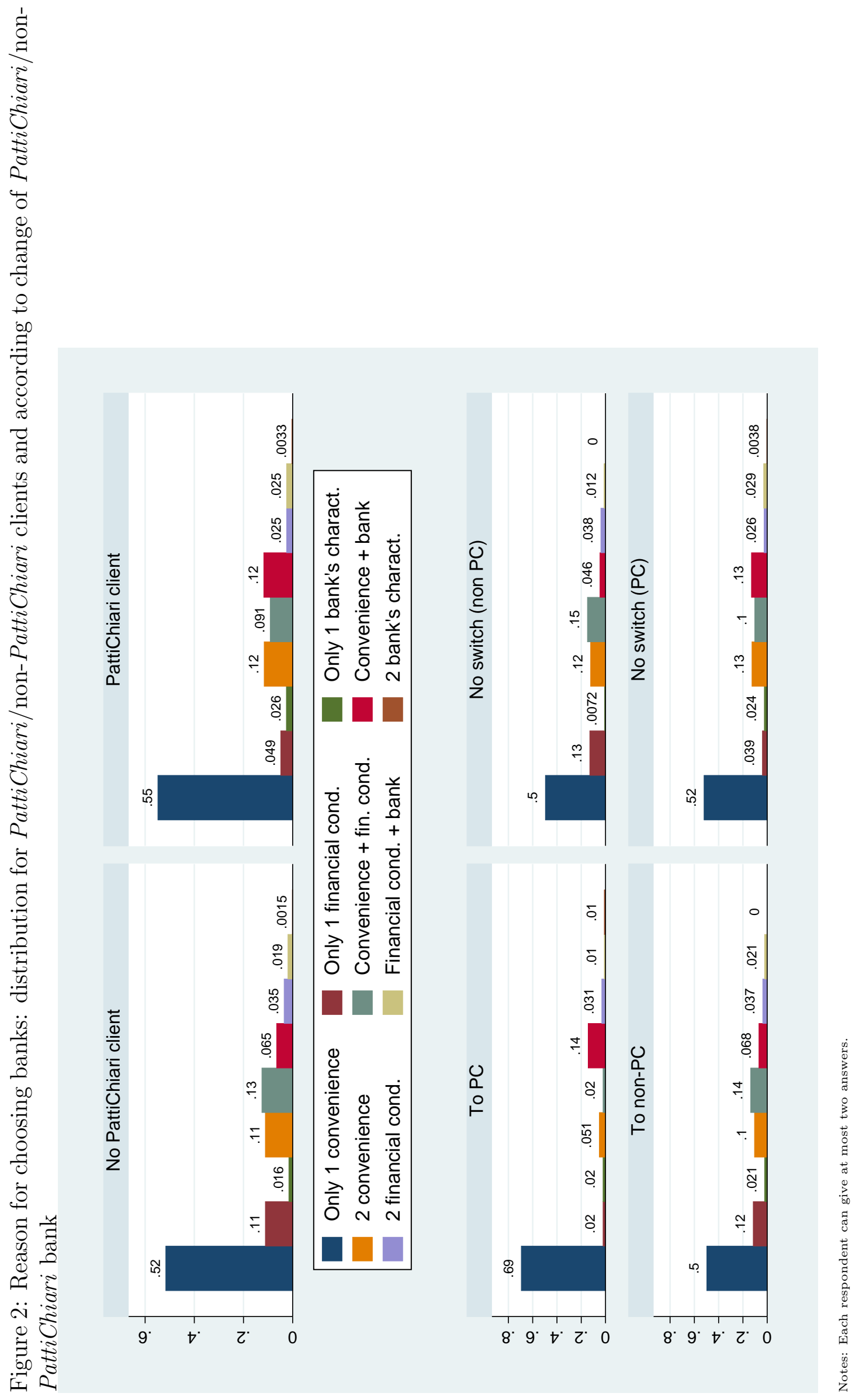




\section{Tables}

Table 1: Bank Costs by PattiChiari Status - Year 2010 (euro)

\begin{tabular}{lcccccc}
\hline \hline $\begin{array}{l}\text { Type } \\
\text { of Bank }\end{array}$ & $\begin{array}{c}\text { Basic } \\
\text { Account } \\
\text { Fees }\end{array}$ & $\begin{array}{c}\text { Debit } \\
\text { Card } \\
\text { Fees }\end{array}$ & $\begin{array}{c}\text { Credit } \\
\text { Card } \\
\text { Fees }\end{array}$ & $\begin{array}{c}\text { Avg. Cost } \\
\text { Bank Transf. } \\
\text { (desk) }\end{array}$ & $\begin{array}{c}\text { Avg. Cost } \\
\text { Bank Transf. } \\
\text { (online) }\end{array}$ & Obs \\
\hline non-Patti-Chiari & 32.5 & 6.78 & 16.0 & 1.76 & 0.38 & 2106 \\
& $(30.0)$ & $(5.72)$ & $(19.9)$ & $(4.61)$ & $(3.67)$ & \\
Patti-Chiari & 36.0 & 4.33 & 14.6 & 2.06 & 0.52 & 6127 \\
& $(38.2)$ & $(5.24)$ & $(13.4)$ & $(6.05)$ & $(4.59)$ & \\
Welch t-test stat. & 4.22 & $17.3(0.00)$ & $3.05(0.00)$ & $2.39(0.00)$ & 1.31 & \\
(p-value) & $(0.00)$ & $(0.00)$ & $(0.00)$ & $(0.00)$ & $(0.19)$ & \\
\hline \hline
\end{tabular}

Source: Bank of Italy Survey on Bank Fees and Expenditures. Notes: an observation is an individual bank account. Due to confidentiality reasons, for each bank, only means and standard deviations of each variable has been provided, together with the number of bank accounts surveyed. The means and standard deviations provided in this table are, thus, combined assuming observations are independent between banks. The Welch t-test for equality of means assumes unequal standard deviations between the two groups.

Table 2: Unconfoundedness of PattiChiari Status With Respect To Credit Services Probit Regression Results (Coefficients and Standard Errors in Parentheses)

\begin{tabular}{lcccc}
\hline \hline & $\begin{array}{c}\text { Prob. of being } \\
\text { Liq. Constrained }\end{array}$ & $\begin{array}{c}\text { Prob. of having } \\
\text { a fixed rate mortg. }\end{array}$ & $\begin{array}{c}\text { Level of } \\
\text { fixed int.rate }\end{array}$ & $\begin{array}{c}\text { Level of } \\
\text { adj. int.rate }\end{array}$ \\
\hline Client of PattiChiari & -0.135 & -0.150 & -0.573 & 0.433 \\
& $(0.094)$ & $(0.288)$ & $(0.764)$ & $(1.189)$ \\
\hline $\mathrm{N}$ & 3454 & 382 & 124 & 103 \\
\hline \hline
\end{tabular}

Notes: ${ }^{*} p<0.1,{ }^{* *} p<0.05,{ }^{* * *} p<0.01$. All regressions include a constant, and province dummies, a quadratic polynomial in age of the household head, dummies for gender and marital status of the household head and for municipality size.

Errors robust to heteroskedasticity and clustered at the province level in parentheses.

See Table A-6 in the appendix for the coefficients of the full list of regressors. 
Table 3: Probability of Being a Client of a PattiChiari Bank - Probit Regression Results (Coefficients, Standard Errors in Parenthesiss And Marginal Effects (At the Mean of the Independent Variables) in Squared Brackets)

\begin{tabular}{|c|c|c|c|}
\hline Only 1 services & $\begin{array}{c}-0.734^{* * *} \\
(0.094) \\
{[-0.266]}\end{array}$ & & \\
\hline Only 1 bank's charact. & $\begin{array}{l}0.280^{*} \\
(0.150) \\
{[0.078]}\end{array}$ & & \\
\hline 2 convenience & $\begin{array}{l}-0.005 \\
(0.082) \\
{[-0.001]}\end{array}$ & & \\
\hline Convenience + services & $\begin{array}{c}-0.454^{* * *} \\
(0.098) \\
{[-0.156]}\end{array}$ & & \\
\hline Convenience + bank & $\begin{array}{c}0.246^{* * *} \\
(0.088) \\
{[0.071]}\end{array}$ & & \\
\hline 2 services & $\begin{array}{c}-0.509^{* * *} \\
(0.164) \\
{[-0.180]}\end{array}$ & & \\
\hline Services + bank & $\begin{array}{l}-0.102 \\
(0.143) \\
{[-0.033]}\end{array}$ & & \\
\hline 2 bank's charact. & $\begin{array}{c}0.365 \\
(0.377) \\
{[0.098]}\end{array}$ & & \\
\hline Only fin. reasons & & $\begin{array}{c}-0.635^{* * *} \\
(0.089) \\
{[-0.227]}\end{array}$ & \\
\hline At least one fin. reason & & & $\begin{array}{c}-0.557^{* * *} \\
(0.065) \\
{[-0.190]}\end{array}$ \\
\hline Age & $\begin{array}{c}0.033^{* * *} \\
(0.011) \\
{[0.010]}\end{array}$ & $\begin{array}{c}0.031^{* * *} \\
(0.011) \\
{[0.010]}\end{array}$ & $\begin{array}{c}0.034^{* * *} \\
(0.011) \\
{[0.011]}\end{array}$ \\
\hline Age sq. & $\begin{array}{c}-0.000 * * * \\
(0.000) \\
{[-0.000]}\end{array}$ & $\begin{array}{c}-0.000 * * * \\
(0.000) \\
{[-0.000]}\end{array}$ & $\begin{array}{c}-0.000 * * * \\
(0.000) \\
{[-0.000]}\end{array}$ \\
\hline Male & $\begin{array}{c}0.169 * * * \\
(0.058) \\
{[0.053]}\end{array}$ & $\begin{array}{c}0.159 * * * \\
(0.058) \\
{[0.050]}\end{array}$ & $\begin{array}{c}0.164^{* * *} \\
(0.059) \\
{[0.051]}\end{array}$ \\
\hline Married & $\begin{array}{l}0.097^{*} \\
(0.058) \\
{[0.030]}\end{array}$ & $\begin{array}{l}0.097^{*} \\
(0.058) \\
{[0.031]}\end{array}$ & $\begin{array}{l}0.106^{*} \\
(0.057) \\
{[0.033]}\end{array}$ \\
\hline Nb. hh components & $\begin{array}{c}0.050^{* *} \\
(0.025) \\
{[0.016]}\end{array}$ & $\begin{array}{l}0.046^{*} \\
(0.025) \\
{[0.014]}\end{array}$ & $\begin{array}{l}0.046^{*} \\
(0.025) \\
{[0.014]}\end{array}$ \\
\hline Municip. $<20.000$ inh. & $\begin{array}{l}-0.143 \\
(0.097) \\
{[-0.045]}\end{array}$ & $\begin{array}{l}-0.147 \\
(0.098) \\
{[-0.047]}\end{array}$ & $\begin{array}{c}-0.144 \\
(0.096) \\
{[-0.046]}\end{array}$ \\
\hline Municip. 40.000-500.000 inh. & $\begin{array}{c}0.143 \\
(0.106) \\
{[0.044]}\end{array}$ & $\begin{array}{l}0.132 \\
(0.106) \\
{[0.041]}\end{array}$ & $\begin{array}{c}0.149 \\
(0.107) \\
{[0.046]}\end{array}$ \\
\hline Municip. 500.000+ inh. & $\begin{array}{c}0.310^{* * *} \\
(0.081) \\
{[0.087]}\end{array}$ & $\begin{array}{c}0.283^{* * *} \\
(0.076) \\
{[0.081]}\end{array}$ & $\begin{array}{c}0.311^{* * *} \\
(0.083) \\
{[0.088]}\end{array}$ \\
\hline $\mathrm{N}$ & 4951 & 4951 & 4951 \\
\hline
\end{tabular}

Notes: ${ }^{*} p<0.1,{ }^{* *} p<0.05,{ }^{* * *} p<0.01$. All regressions include a constant, and province dummies.

Errors robust to heteroskedasticity and clustered at the province level in parentheses; marginal effect in squared brackets. 
Table 4: Summary Statistics

\begin{tabular}{lccc}
\hline \hline \multicolumn{1}{c}{ Variable } & Mean & Std. Dev. & N \\
\hline Financial Literacy & & & \\
Fin. lit. (nb. correct/3) & 1.926 & 0.983 & 4972 \\
Fin. lit. (3/3 correct) & 0.34 & 0.474 & 4972 \\
Inflation correct & 0.74 & 0.439 & 4972 \\
Loan correct & 0.639 & 0.48 & 4972 \\
Portf. div. correct & 0.547 & 0.498 & 4972
\end{tabular}

PattiChiari Dummies

$\begin{array}{llll}p c & 0.729 & 0.445 & 4972 \\ p c \_n o b n k & 0.616 & 0.486 & 5885 \\ p c \_a l l & 0.537 & 0.499 & 5885 \\ \text { pc_atleast } & 0.646 & 0.478 & 5927\end{array}$

Outcomes

$\begin{array}{llll}\text { Financial assets } & 19.128 & 22.149 & 4972\end{array}$

$\begin{array}{llll}\text { Savings } & 7.933 & 12.886 & 4972\end{array}$

$\begin{array}{llll}\text { Planning for retirement } & 0.452 & 0.498 & 2757\end{array}$

$\begin{array}{llll}\text { Stock market participation } & 0.115 & 0.319 & 4972\end{array}$

Baseline Controls

$\begin{array}{lccc}\text { Male } & 0.556 & 0.497 & 4972 \\ \text { Age } & 58.465 & 15.374 & 4972 \\ \text { Married } & 0.636 & 0.481 & 4972 \\ \text { Nb. hh components } & 2.47 & 1.211 & 4972 \\ \text { Municip. 20.000-40.000 inh. } & 0.193 & 0.395 & 4972 \\ \text { Municip. 40.000-500.000 inh. } & 0.446 & 0.497 & 4972 \\ \text { Municip. 500.000+ inh. } & 0.1 & 0.3 & 4972\end{array}$

\section{Motivations}

$\begin{array}{llll}\text { Only } 1 \text { services } & 0.066 & 0.248 & 4972\end{array}$

Only 1 bank's charact. $\quad 0.023 \quad 0.15 \quad 4972$

$\begin{array}{llll}2 \text { convenience } & 0.115 & 0.319 & 4972\end{array}$

$\begin{array}{llll}\text { Convenience }+ \text { services } & 0.101 & 0.301 & 4972\end{array}$

$\begin{array}{llll}\text { Convenience }+ \text { bank } & 0.103 & 0.304 & 4972\end{array}$

$\begin{array}{llll}2 \text { services } & 0.027 & 0.163 & 4972\end{array}$

$\begin{array}{llll}\text { Services + bank } & 0.023 & 0.151 & 4972\end{array}$

2 bank's charact. $\quad 0.003 \quad 0.053 \quad 4972$

Additional Controls

\begin{tabular}{lccc} 
High trust & 0.561 & 0.496 & 4972 \\
Length relat. & 3.608 & 0.820 & 4972 \\
Years of education & 9.44 & 4.54 & 4972 \\
\hline \hline
\end{tabular}


Table 5: Effect of Financial Literacy on Financial Assets

\begin{tabular}{|c|c|c|c|c|}
\hline & 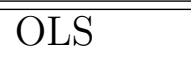 & 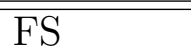 & ITT & 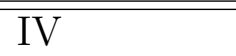 \\
\hline Fin. lit. (nb. correct/3) & $\begin{array}{l}3.759 * * * \\
(0.679)\end{array}$ & & & $\begin{array}{l}17.464^{* * *} \\
(2.918)\end{array}$ \\
\hline Client of PattiChiari & & $\begin{array}{c}0.281^{* * *} \\
(0.037)\end{array}$ & $\begin{array}{l}4.906^{* * *} \\
(0.831)\end{array}$ & \\
\hline Age & $\begin{array}{l}1.107^{* * *} \\
(0.135)\end{array}$ & $\begin{array}{l}0.048^{* * *} \\
(0.007)\end{array}$ & $\begin{array}{l}1.244^{* * *} \\
(0.141)\end{array}$ & $\begin{array}{c}0.408^{* *} \\
(0.198)\end{array}$ \\
\hline Age sq. & $\begin{array}{l}-0.008^{* * *} \\
(0.001)\end{array}$ & $\begin{array}{l}-0.001^{* * *} \\
(0.000)\end{array}$ & $\begin{array}{l}-0.009^{* * *} \\
(0.001)\end{array}$ & $\begin{array}{l}-0.000 \\
(0.002)\end{array}$ \\
\hline Male & $\begin{array}{l}2.038^{* * *} \\
(0.724)\end{array}$ & $\begin{array}{l}0.208^{* * *} \\
(0.026)\end{array}$ & $\begin{array}{l}2.668^{* * *} \\
(0.721)\end{array}$ & $\begin{array}{l}-0.960 \\
(0.894)\end{array}$ \\
\hline Married & $\begin{array}{l}3.414^{* * *} \\
(0.715)\end{array}$ & $\begin{array}{l}0.023 \\
(0.038)\end{array}$ & $\begin{array}{l}3.395^{* * *} \\
(0.747)\end{array}$ & $\begin{array}{l}2.988^{* * *} \\
(0.776)\end{array}$ \\
\hline Nb. hh components & $\begin{array}{l}0.548 \\
(0.364)\end{array}$ & $\begin{array}{l}0.051^{* * *} \\
(0.016)\end{array}$ & $\begin{array}{l}0.696^{*} \\
(0.355)\end{array}$ & $\begin{array}{l}-0.203 \\
(0.465)\end{array}$ \\
\hline Municip. 20.000-40.000 inh. & $\begin{array}{l}-0.181 \\
(1.366)\end{array}$ & $\begin{array}{l}-0.038 \\
(0.071)\end{array}$ & $\begin{array}{l}-0.481 \\
(1.411)\end{array}$ & $\begin{array}{l}0.191 \\
(1.532)\end{array}$ \\
\hline Municip. 40.000-500.000 inh. & $\begin{array}{l}1.161 \\
(1.475)\end{array}$ & $\begin{array}{l}-0.016 \\
(0.068)\end{array}$ & $\begin{array}{l}0.782 \\
(1.410)\end{array}$ & $\begin{array}{l}1.062 \\
(1.939)\end{array}$ \\
\hline Municip. 500.000+ inh. & $\begin{array}{l}2.625 \\
(2.500)\end{array}$ & $\begin{array}{l}0.197 \\
(0.129)\end{array}$ & $\begin{array}{l}2.882 \\
(2.369)\end{array}$ & $\begin{array}{c}-0.561 \\
(3.735)\end{array}$ \\
\hline Province FE & $\mathrm{Y}$ & $\mathrm{Y}$ & $\mathrm{Y}$ & $\mathrm{Y}$ \\
\hline $\begin{array}{l}\mathrm{N} \\
\text { Ftest }\end{array}$ & 4972 & 4972 & 4972 & $\begin{array}{l}4972 \\
57.095\end{array}$ \\
\hline
\end{tabular}


Table 6: Effect of Financial Literacy on Financial Assets, Controlling for Reasons (Baseline Specification)

\begin{tabular}{|c|c|c|c|c|}
\hline & $\overline{\text { OLS }}$ & 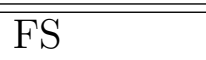 & ITT & $\overline{\mathrm{IV}}$ \\
\hline Fin. lit. (nb. correct/3) & $\begin{array}{l}3.649 * * * \\
(0.666)\end{array}$ & & & $\begin{array}{l}16.724^{* * *} \\
(2.710)\end{array}$ \\
\hline Client of PattiChiari & & $\begin{array}{l}0.296^{* * * *} \\
(0.039)\end{array}$ & $\begin{array}{l}4.953^{* * *} \\
(0.778)\end{array}$ & \\
\hline Age & $\begin{array}{l}1.082^{* * *} \\
(0.137)\end{array}$ & $\begin{array}{l}0.047^{* * *} \\
(0.007)\end{array}$ & $\begin{array}{l}1.213^{* * *} \\
(0.141)\end{array}$ & $\begin{array}{l}0.426^{* *} \\
(0.190)\end{array}$ \\
\hline Age sq. & $\begin{array}{l}-0.008^{* * * *} \\
(0.001)\end{array}$ & $\begin{array}{l}-0.000^{* * *} \\
(0.000)\end{array}$ & $\begin{array}{l}-0.009^{* * *} \\
(0.001)\end{array}$ & $\begin{array}{l}-0.001 \\
(0.002)\end{array}$ \\
\hline Male & $\begin{array}{l}2.007^{* * *} \\
(0.708)\end{array}$ & $\begin{array}{l}0.200^{* * *} \\
(0.026)\end{array}$ & $\begin{array}{l}2.555^{* * *} \\
(0.698)\end{array}$ & $\begin{array}{l}-0.796 \\
(0.830)\end{array}$ \\
\hline Married & $\begin{array}{l}3.429^{* * *} \\
(0.690)\end{array}$ & $\begin{array}{l}0.021 \\
(0.037)\end{array}$ & $\begin{array}{l}3.395^{* * * *} \\
(0.722)\end{array}$ & $\begin{array}{l}3.036^{* * *} \\
(0.746)\end{array}$ \\
\hline Nb. hh components & $\begin{array}{l}0.514 \\
(0.361)\end{array}$ & $\begin{array}{l}0.050 * * * \\
(0.017)\end{array}$ & $\begin{array}{l}0.645^{*} \\
(0.356)\end{array}$ & $\begin{array}{l}-0.189 \\
(0.443)\end{array}$ \\
\hline Municip. 20.000-40.000 inh. & $\begin{array}{l}-0.367 \\
(1.366)\end{array}$ & $\begin{array}{l}-0.044 \\
(0.070)\end{array}$ & $\begin{array}{l}-0.692 \\
(1.406)\end{array}$ & $\begin{array}{l}0.041 \\
(1.521)\end{array}$ \\
\hline Municip. 40.000-500.000 inh. & $\begin{array}{l}1.021 \\
(1.504)\end{array}$ & $\begin{array}{l}-0.025 \\
(0.067)\end{array}$ & $\begin{array}{l}0.602 \\
(1.434)\end{array}$ & $\begin{array}{l}1.016 \\
(1.920)\end{array}$ \\
\hline Municip. 500.000+ inh. & $\begin{array}{l}2.610 \\
(2.492)\end{array}$ & $\begin{array}{l}0.191 \\
(0.133)\end{array}$ & $\begin{array}{l}2.816 \\
(2.395)\end{array}$ & $\begin{array}{l}-0.373 \\
(3.611)\end{array}$ \\
\hline Only 1 services & $\begin{array}{l}1.083 \\
(1.345)\end{array}$ & $\begin{array}{l}0.089 \\
(0.064)\end{array}$ & $\begin{array}{l}2.282^{*} \\
(1.339)\end{array}$ & $\begin{array}{l}0.801 \\
(1.633)\end{array}$ \\
\hline Only 1 bank's charact. & $\begin{array}{l}2.692 \\
(2.107)\end{array}$ & $\begin{array}{l}-0.094 \\
(0.065)\end{array}$ & $\begin{array}{l}2.103 \\
(2.081)\end{array}$ & $\begin{array}{l}3.684 \\
(2.247)\end{array}$ \\
\hline 2 convenience & $\begin{array}{l}6.079^{* * *} \\
(1.270)\end{array}$ & $\begin{array}{l}0.088 \\
(0.055)\end{array}$ & $\begin{array}{l}6.411^{* * *} \\
(1.316)\end{array}$ & $\begin{array}{l}4.938^{* * *} \\
(1.294)\end{array}$ \\
\hline Convenience + services & $\begin{array}{l}1.487 \\
(1.245)\end{array}$ & $\begin{array}{l}0.151^{* *} \\
(0.068)\end{array}$ & $\begin{array}{l}2.535^{* *} \\
(1.247)\end{array}$ & $\begin{array}{l}0.012 \\
(1.569)\end{array}$ \\
\hline Convenience + bank & $\begin{array}{l}5.045^{* * *} \\
(1.297)\end{array}$ & $\begin{array}{l}0.092 \\
(0.060)\end{array}$ & $\begin{array}{l}5.145^{* * *} \\
(1.300)\end{array}$ & $\begin{array}{l}3.612^{* *} \\
(1.408)\end{array}$ \\
\hline 2 services & $\begin{array}{l}4.093^{* *} \\
(1.873)\end{array}$ & $\begin{array}{l}0.241^{* * *} \\
(0.075)\end{array}$ & $\begin{array}{l}5.551^{* * *} \\
(1.934)\end{array}$ & $\begin{array}{l}1.515 \\
(1.943)\end{array}$ \\
\hline Services + bank & $\begin{array}{l}2.296 \\
(2.257)\end{array}$ & $\begin{array}{l}0.167^{*} \\
(0.086)\end{array}$ & $\begin{array}{l}3.023 \\
(2.208)\end{array}$ & $\begin{array}{l}0.222 \\
(2.548)\end{array}$ \\
\hline 2 bank's charact. & $\begin{array}{l}4.976 \\
(5.292)\end{array}$ & $\begin{array}{l}0.065 \\
(0.172)\end{array}$ & $\begin{array}{l}4.974 \\
(5.436)\end{array}$ & $\begin{array}{l}3.880 \\
(5.041)\end{array}$ \\
\hline Province FE & $\mathrm{Y}$ & Y & $\mathrm{Y}$ & $\mathrm{Y}$ \\
\hline $\begin{array}{l}\mathrm{N} \\
\text { Ftest }\end{array}$ & 4972 & 4972 & 4972 & $\begin{array}{l}4972 \\
58.651\end{array}$ \\
\hline
\end{tabular}


Table 7: Effect of Financial Literacy on Financial Assets, Adding Additional Controls to the Baseline Specification: Trust, Length of Relation with Bank, Years of Education

\begin{tabular}{|c|c|c|c|c|}
\hline & OLS & $\overline{\mathrm{FS}}$ & ITT & IV \\
\hline \multicolumn{5}{|c|}{ Additional control: Trust } \\
\hline Fin. lit. (nb. correct/3) & $\begin{array}{l}3.644^{* * *} \\
(0.666)\end{array}$ & & & $\begin{array}{l}16.766^{\text {*** }} \\
(2.797)\end{array}$ \\
\hline Client of PattiChiari & & $\begin{array}{l}0.301^{* * *} \\
(0.039)\end{array}$ & $\begin{array}{l}5.051^{* * *} \\
(0.788)\end{array}$ & \\
\hline High trust & $\begin{array}{l}0.536 \\
(0.707)\end{array}$ & $\begin{array}{l}0.053 \\
(0.042)\end{array}$ & $\begin{array}{l}1.015 \\
(0.676)\end{array}$ & $\begin{array}{l}0.128 \\
(1.040)\end{array}$ \\
\hline \multicolumn{5}{|c|}{ Additional control: Length of Relation with Bank } \\
\hline Fin. lit. (nb. correct/3) & $\begin{array}{l}3.554^{* * *} \\
(0.664)\end{array}$ & & & $\begin{array}{l}15.214^{\text {*** }} \\
(2.727)\end{array}$ \\
\hline Client of PattiChiari & & $\begin{array}{l}0.287^{* * *} \\
(0.040)\end{array}$ & $\begin{array}{l}4.364^{* * *} \\
(0.753)\end{array}$ & \\
\hline Length relat. & $\begin{array}{l}2.246^{* * *} \\
(0.521)\end{array}$ & $\begin{array}{l}0.033 \\
(0.027)\end{array}$ & $\begin{array}{l}2.094^{* * *} \\
(0.518)\end{array}$ & $\begin{array}{l}1.589^{* *} \\
(0.625)\end{array}$ \\
\hline \multicolumn{5}{|c|}{ Additional control: Years of education } \\
\hline Fin. lit. (nb. correct/3) & $\begin{array}{l}2.284^{* * *} \\
(0.642)\end{array}$ & & & $\begin{array}{l}12.226^{* * *} \\
(3.438)\end{array}$ \\
\hline Client of PattiChiari & & $\begin{array}{l}0.229^{* * *} \\
(0.035)\end{array}$ & $\begin{array}{l}2.797^{* * *} \\
(0.770)\end{array}$ & \\
\hline Years of education & $\begin{array}{l}1.411^{* * *} \\
(0.094)\end{array}$ & $\begin{array}{l}0.046^{* * *} \\
(0.004)\end{array}$ & $\begin{array}{l}1.479^{* * *} \\
(0.089)\end{array}$ & $\begin{array}{l}0.914^{* * *} \\
(0.214)\end{array}$ \\
\hline Province FE & $\mathrm{Y}$ & $\mathrm{Y}$ & $\mathrm{Y}$ & $\mathrm{Y}$ \\
\hline Controls & $\mathrm{Y}$ & $\mathrm{Y}$ & $\mathrm{Y}$ & $\mathrm{Y}$ \\
\hline $\mathrm{N}$ & 4972 & 4972 & 4972 & 4972 \\
\hline
\end{tabular}

Notes: ${ }^{*} p<0.1,{ }^{* *} p<0.05,{ }^{* * *} p<0.01$. All regressions include the controls in the baseline specification (Table 6). Heteroskedasticity-robust standard errors clustered at the province level in parentheses. 
Table 8: Robustness: Different Measures of Financial Literacy of Financial Literacy: First stage and Instrumental Variable Estimates. Measure of the Instrument is Always an Indicator of Whether the Main Bank is a PattiChiari Bank pc

\begin{tabular}{|c|c|c|c|c|c|}
\hline & $\begin{array}{l}\text { Nb. of Correct } \\
\text { Answers } \\
\text { Out of } 3\end{array}$ & $\begin{array}{l}\text { Indicator for } \\
3 \text { Answers } \\
\text { Correct Out of } 3\end{array}$ & $\begin{array}{l}\text { Indicator for } \\
\text { Inflation Quest. } \\
\text { Correct }\end{array}$ & $\begin{array}{l}\text { Indicator for } \\
\text { Loan Quest. } \\
\text { Correct }\end{array}$ & $\begin{array}{l}\text { Indicator for } \\
\text { Portfolio divers. } \\
\text { Quest. Correct }\end{array}$ \\
\hline Avg. & 1.926 & 0.34 & 0.74 & 0.639 & 0.547 \\
\hline FS & $\begin{array}{l}0.296^{* * *} \\
(0.039)\end{array}$ & $\begin{array}{l}0.067^{* * *} \\
(0.016)\end{array}$ & $\begin{array}{l}0.121^{* * *} \\
(0.020)\end{array}$ & $\begin{array}{l}0.082^{* * *} \\
(0.014)\end{array}$ & $\begin{array}{l}0.093^{* * *} \\
(0.020)\end{array}$ \\
\hline OLS & $\begin{array}{l}3.649^{* * *} \\
(0.666)\end{array}$ & $\begin{array}{l}6.456^{* * *} \\
(1.139)\end{array}$ & $\begin{array}{l}4.449^{* * *} \\
(1.304)\end{array}$ & $\begin{array}{l}2.799^{* * *} \\
(0.901)\end{array}$ & $\begin{array}{l}7.700^{* * *} \\
(1.226)\end{array}$ \\
\hline IV & $\begin{array}{l}16.724^{* * *} \\
(2.710)\end{array}$ & $\begin{array}{l}73.632^{* * *} \\
(19.293)\end{array}$ & $\begin{array}{l}40.937^{* * *} \\
(7.889)\end{array}$ & $\begin{array}{l}60.169^{* * *} \\
(12.593)\end{array}$ & $\begin{array}{l}53.347^{* * *} \\
(11.470)\end{array}$ \\
\hline F-test & 58.651 & 17.158 & 36.336 & 36.727 & 21.816 \\
\hline
\end{tabular}

Notes: ${ }^{*} p<0.1,{ }^{* *} p<0.05,{ }^{* * *} p<0.01$. All regressions include the controls in the baseline specification (Table 6). Heteroskedasticity-robust standard errors clustered at the province level in parentheses.

Table 9: Robustness: Different Measures of the Instrumental Variable: First Stage, Intention to Treat and Instrumental Variables Estimates. Measure of Financial Literacy is Always the Number of Correct Answers Out of 3)

\begin{tabular}{|c|c|c|c|c|}
\hline & $p c$ & $p c \_n o b n k$ & $p c \_a l l$ & pc_atleast \\
\hline Avg. & 0.729 & 0.616 & 0.537 & 0.646 \\
\hline FS & $\begin{array}{l}0.296^{* * *} \\
(0.039)\end{array}$ & $\begin{array}{l}0.191^{* * *} \\
(0.033)\end{array}$ & $\begin{array}{l}0.151^{* * *} \\
(0.031)\end{array}$ & $\begin{array}{l}0.210^{* * *} \\
(0.033)\end{array}$ \\
\hline ITT & $\begin{array}{l}4.953^{* * *} \\
(0.778)\end{array}$ & $\begin{array}{l}2.970^{* * *} \\
(0.715)\end{array}$ & $\begin{array}{l}1.163^{*} \\
(0.676)\end{array}$ & $\begin{array}{l}4.413^{* * *} \\
(0.647)\end{array}$ \\
\hline IV & $\begin{array}{l}16.724^{* * *} \\
(2.710)\end{array}$ & $\begin{array}{l}15.550^{* * *} \\
(3.571)\end{array}$ & $\begin{array}{l}7.688^{*} \\
(4.187)\end{array}$ & $\begin{array}{l}20.998^{* * *} \\
(3.821)\end{array}$ \\
\hline F-test & 58.651 & 33.680 & 23.176 & 40.910 \\
\hline
\end{tabular}

Notes: ${ }^{*} p<0.1,{ }^{* *} p<0.05,{ }^{* * *} p<0.01$. All regressions include the controls in the baseline specification (Table 6). Heteroskedasticity-robust standard errors clustered at the province level in parentheses. 
Table 10: Effect of Financial Literacy on Financial Assets: 2006-2010 sample.

\section{Data: Repeated Cross-Section}

\begin{tabular}{|c|c|c|c|c|}
\hline & OLS & FS & ITT & IV \\
\hline Fin. lit. (nb. correct/2) & $\begin{array}{c}2.875^{* * * *} \\
(0.391)\end{array}$ & & & $\begin{array}{c}26.049^{* * *} \\
(2.738)\end{array}$ \\
\hline Client of PattiChiari & & $\begin{array}{c}0.209^{* * *} \\
(0.019)\end{array}$ & $\begin{array}{c}5.440^{* * *} \\
(0.457)\end{array}$ & \\
\hline $\mathrm{N}$ & 12413 & 12413 & 12413 & 12413 \\
\hline Ftest & & & & 123.898 \\
\hline
\end{tabular}

\section{Data: Panel Individuals Only}

\begin{tabular}{|c|c|c|c|c|}
\hline & OLS & FS & ITT & IV \\
\hline Fin. lit. (nb. correct/2) & $\begin{array}{c}3.126^{* * *} \\
(0.553)\end{array}$ & & & $\begin{array}{c}33.936^{* * *} \\
(6.182)\end{array}$ \\
\hline Client of PattiChiari & & $\begin{array}{c}0.158^{* * * *} \\
(0.026)\end{array}$ & $\begin{array}{c}5.373^{* * *} \\
(0.794)\end{array}$ & \\
\hline $\mathrm{N}$ & 5440 & 5440 & 5440 & 5440 \\
\hline Ftest & & & & 38.494 \\
\hline
\end{tabular}


Table 11: Association and Causal Effect of Financial Literacy on Financial Assets. Instrumenting using information on 'bank-switchers' in two years (between waves)

HHs observed in 2008 and 2010

\begin{tabular}{lcccc} 
& OLS & FS & ITT & IV \\
\hline Fin. lit. (nb. correct/2) & $2.890^{* * *}$ & & \multicolumn{2}{c}{$31.410^{* * *}$} \\
& $(0.717)$ & & & $(6.622)$ \\
Switches to Client of PattiChiari & & -0.073 & -1.099 & \\
& & $(0.074)$ & $(2.109)$ & \\
Stays Client of Non-PattiChiari & & $-0.190^{* * *}$ & $-6.824^{* * *}$ & \\
& & $(0.042)$ & $(0.927)$ & \\
Switches to Client of Non-PattiChiari & & $-0.136^{* * *}$ & -1.609 & \\
& & $(0.046)$ & $(1.508)$ & \\
& 3373 & 3373 & 3373 & 3373 \\
N & & & & 0.221 \\
\hline \hline
\end{tabular}

HHs observed in 2006 and 2010

\begin{tabular}{lcccc} 
& OLS & FS & ITT & IV \\
\hline Fin. lit. (nb. correct/2) & $2.351^{*}$ & & \multicolumn{2}{c}{$20.658^{* * *}$} \\
& $(1.290)$ & & & $(7.141)$ \\
Switches to Client of PattiChiari & & -0.066 & -0.155 & \\
& & $(0.105)$ & $(2.660)$ & \\
Stays Client of Non-PattiChiari & & $-0.236^{* * *}$ & $-5.058^{* * *}$ & \\
& & $(0.070)$ & $(1.447)$ & \\
Switches to Client of Non-PattiChiari & & $-0.129^{*}$ & -2.035 & \\
& & $(0.071)$ & $(2.910)$ & \\
\hline N & 1610 & 1610 & 1610 & 1610 \\
Hansen J p-value & & & & 0.913 \\
\hline \hline
\end{tabular}

Notes: ${ }^{*} p<0.1,{ }^{* *} p<0.05,{ }^{* * *} p<0.01$. All regressions include the controls in the baseline specification (Table 6). Heteroskedasticity-robust standard errors clustered at the province level in parentheses. 
Table 12: Effect of financial literacy on other outcomes

$\begin{array}{llll}\text { OLS } & \text { FS } & \text { ITT } & \text { IV }\end{array}$

\section{Savings}

Fin. lit. (nb. correct/3)

$0.656^{* *}$

$6.760^{* * *}$

Client of PattiChiari

$(0.314)$

$(1.613)$

$\mathrm{N}$

4959

$0.297^{* * *} \quad 2.006^{* * *}$

(0.038) (0.422)

Ftest

$4959 \quad 4959 \quad 4959$

59.955

\section{Planning for retirement}

Fin. lit. (nb. correct/3)

$$
0.046^{* * *}
$$

$0.267 * *$

Client of PattiChiari

$$
\text { (0.014) }
$$

N

2753

$0.239 * * *$

$0.064^{* *}$

$(0.048) \quad(0.027)$

Ftest

2753

2753

2753

24.815

\section{Stock market participation}

Fin. lit. (nb. correct/3)

Client of PattiChiari

N

Ftest
$0.033^{* * *}$

$0.191^{* * *}$

Notes: ${ }^{*} p<0.1,{ }^{* *} p<0.05,{ }^{* * *} p<0.01$. All regressions include the controls in the baseline specification (Table 6$)$.

Errors robust to heteroskedasticity and clustered at the province level in parentheses. 
A Additional Tables 
Table A-1: Robustness: Controlling for Municipality Fixed Effects

\begin{tabular}{|c|c|c|c|c|}
\hline & OLS & FS & ITT & IV \\
\hline Fin. lit. (nb. correct/3) & $\begin{array}{l}3.806^{* * *} \\
(0.501)\end{array}$ & & & $\begin{array}{l}21.933^{* * *} \\
(3.640)\end{array}$ \\
\hline Client of PattiChiari & & $\begin{array}{l}0.263^{* * *} \\
(0.037)\end{array}$ & $\begin{array}{l}5.763^{* * *} \\
(0.736)\end{array}$ & \\
\hline Age & $\begin{array}{l}1.099^{* * *} \\
(0.139)\end{array}$ & $\begin{array}{l}0.053^{* * *} \\
(0.006)\end{array}$ & $\begin{array}{l}1.235^{* * *} \\
(0.140)\end{array}$ & $\begin{array}{l}0.079 \\
(0.245)\end{array}$ \\
\hline Age sq. & $\begin{array}{l}-0.008^{* * *} \\
(0.001)\end{array}$ & $\begin{array}{l}-0.001^{* * *} \\
(0.000)\end{array}$ & $\begin{array}{l}-0.009^{* * *} \\
(0.001)\end{array}$ & $\begin{array}{l}0.003 \\
(0.002)\end{array}$ \\
\hline Male & $\begin{array}{l}1.920^{* * *} \\
(0.666)\end{array}$ & $\begin{array}{l}0.175^{* * *} \\
(0.031)\end{array}$ & $\begin{array}{l}2.390 * * * \\
(0.639)\end{array}$ & $\begin{array}{l}-1.441 \\
(0.958)\end{array}$ \\
\hline Married & $\begin{array}{l}3.703^{* * *} \\
(0.672)\end{array}$ & $\begin{array}{l}0.008 \\
(0.038)\end{array}$ & $\begin{array}{l}3.592^{* * *} \\
(0.708)\end{array}$ & $\begin{array}{l}3.415^{* * *} \\
(0.868)\end{array}$ \\
\hline Nb. hh components & $\begin{array}{l}-0.166 \\
(0.387)\end{array}$ & $\begin{array}{l}0.053^{* * *} \\
(0.017)\end{array}$ & $\begin{array}{l}0.016 \\
(0.392)\end{array}$ & $\begin{array}{l}-1.139^{* *} \\
(0.503)\end{array}$ \\
\hline Municip. 20.000-40.000 inh. & $\begin{array}{l}2.070 \\
(1.640)\end{array}$ & $\begin{array}{l}-0.111 \\
(0.098)\end{array}$ & $\begin{array}{l}1.472 \\
(1.710)\end{array}$ & $\begin{array}{l}3.896^{*} \\
(2.337)\end{array}$ \\
\hline Municip. 40.000-500.000 inh. & $\begin{array}{l}-0.464 \\
(1.356)\end{array}$ & $\begin{array}{l}-0.079 \\
(0.071)\end{array}$ & $\begin{array}{l}-1.011 \\
(1.415)\end{array}$ & $\begin{array}{l}0.719 \\
(1.616)\end{array}$ \\
\hline Municip. 500.000+ inh. & $\begin{array}{l}-5.195 \\
(3.361)\end{array}$ & $\begin{array}{l}0.348 \\
(0.289)\end{array}$ & $\begin{array}{l}-4.744 \\
(3.364)\end{array}$ & $\begin{array}{l}-12.373^{* *} \\
(6.299)\end{array}$ \\
\hline Only 1 services & $\begin{array}{l}0.931 \\
(1.305)\end{array}$ & $\begin{array}{l}0.072 \\
(0.075)\end{array}$ & $\begin{array}{l}2.298^{*} \\
(1.297)\end{array}$ & $\begin{array}{l}0.717 \\
(1.957)\end{array}$ \\
\hline Only 1 bank's charact. & $\begin{array}{l}0.725 \\
(1.967)\end{array}$ & $\begin{array}{l}-0.039 \\
(0.076)\end{array}$ & $\begin{array}{l}0.329 \\
(1.947)\end{array}$ & $\begin{array}{l}1.178 \\
(2.418)\end{array}$ \\
\hline 2 convenience & $\begin{array}{l}5.793^{* * *} \\
(1.087)\end{array}$ & $\begin{array}{l}0.057 \\
(0.054)\end{array}$ & $\begin{array}{l}6.088^{* * *} \\
(1.120)\end{array}$ & $\begin{array}{l}4.841^{* * *} \\
(1.345)\end{array}$ \\
\hline Convenience + services & $\begin{array}{l}2.565^{*} \\
(1.300)\end{array}$ & $\begin{array}{l}0.118^{*} \\
(0.071)\end{array}$ & $\begin{array}{l}3.522^{* * *} \\
(1.281)\end{array}$ & $\begin{array}{l}0.925 \\
(1.829)\end{array}$ \\
\hline Convenience + bank & $\begin{array}{l}5.265^{* * *} \\
(1.275)\end{array}$ & $\begin{array}{l}0.056 \\
(0.053)\end{array}$ & $\begin{array}{l}5.120^{* * *} \\
(1.274)\end{array}$ & $\begin{array}{l}3.898^{* *} \\
(1.559)\end{array}$ \\
\hline 2 services & $\begin{array}{l}4.510^{* *} \\
(1.859)\end{array}$ & $\begin{array}{l}0.219^{* * *} \\
(0.082)\end{array}$ & $\begin{array}{l}5.910^{* * *} \\
(1.884)\end{array}$ & $\begin{array}{l}1.114 \\
(2.244)\end{array}$ \\
\hline Services + bank & $\begin{array}{l}2.268 \\
(2.464)\end{array}$ & $\begin{array}{l}0.187^{* *} \\
(0.082)\end{array}$ & $\begin{array}{l}2.900 \\
(2.394)\end{array}$ & $\begin{array}{l}-1.194 \\
(2.842)\end{array}$ \\
\hline 2 bank's charact. & $\begin{array}{l}8.498 \\
(5.361)\end{array}$ & $\begin{array}{l}0.058 \\
(0.151)\end{array}$ & $\begin{array}{l}8.187 \\
(5.410)\end{array}$ & $\begin{array}{l}6.922 \\
(6.055)\end{array}$ \\
\hline $\begin{array}{l}\mathrm{N} \\
\text { Ftest }\end{array}$ & 4969 & 4969 & 4969 & $\begin{array}{l}4969 \\
49.640\end{array}$ \\
\hline
\end{tabular}

Errors robust to heteroskedasticity or clustered at the province level in parentheses; marginal dummiect in squared brackets. 
Table A-2: Robustness: Different Measures of the Instrumental Variable Over Time

\begin{tabular}{|c|c|c|c|c|}
\hline & OLS & FS & ITT & IV \\
\hline Fin. lit. (nb. correct/3) & $\begin{array}{l}3.522^{* * *} \\
(0.792)\end{array}$ & & & $\begin{array}{l}18.964^{* * *} \\
(4.322)\end{array}$ \\
\hline Client of PattiChiari in 2008 & & $\begin{array}{l}0.280^{* * *} \\
(0.059)\end{array}$ & $\begin{array}{l}5.317^{* * *} \\
(0.924)\end{array}$ & \\
\hline $\mathrm{N}$ & & & & 2715 \\
\hline Ftest & & & & 22.932 \\
\hline Fin. lit. (nb. correct/3) & $\begin{array}{l}3.431^{* * *} \\
(0.890)\end{array}$ & & & $\begin{array}{l}21.431^{* * *} \\
(7.563)\end{array}$ \\
\hline Client of PattiChiari in 2006 & & $\begin{array}{l}0.225^{* * *} \\
(0.075)\end{array}$ & $\begin{array}{l}4.823^{* * *} \\
(1.249)\end{array}$ & \\
\hline $\mathrm{N}$ & & & & 1952 \\
\hline
\end{tabular}

Errors robust to heteroskedasticity or clustered at the province level in parentheses.

Table A-3: Association and Causal Effect of Financial Literacy on Financial Assets. 2010 subsamples.

\begin{tabular}{|c|c|c|c|c|}
\hline \multicolumn{5}{|c|}{ Household living in urban areas } \\
\hline & OLS & FS & ITT & IV \\
\hline Fin. lit. (nb. correct/2) & $\begin{array}{c}3.650^{* * *} \\
(0.735)\end{array}$ & & & $\begin{array}{c}17.296^{* * * *} \\
(3.150)\end{array}$ \\
\hline Client of PattiChiari & & $\begin{array}{c}0.292^{* * *} \\
(0.044)\end{array}$ & $\begin{array}{c}5.057^{* * *} \\
(0.918)\end{array}$ & \\
\hline $\mathrm{N}$ & 4333 & 4333 & 4333 & 4333 \\
\hline Ftest & & & & 45.102 \\
\hline \multicolumn{5}{|c|}{ Household living in municipalities below 40.000 inhabitants } \\
\hline & OLS & FS & ITT & IV \\
\hline Fin. lit. (nb. correct/3) & $\begin{array}{c}3.701^{* * *} \\
(0.757)\end{array}$ & & & $\begin{array}{c}12.167^{* * *} \\
(3.093)\end{array}$ \\
\hline Client of PattiChiari & & $\begin{array}{c}0.306^{* * *} \\
(0.057)\end{array}$ & $\begin{array}{c}3.722^{* * *} \\
(0.984)\end{array}$ & \\
\hline $\mathrm{N}$ & 2258 & 2258 & 2258 & 2258 \\
\hline Ftest & & & & 29.166 \\
\hline \multicolumn{5}{|c|}{ Household living in municipalities above 40.000 inhabitants } \\
\hline & OLS & FS & ITT & IV \\
\hline Fin. lit. (nb. correct/3) & $\begin{array}{c}3.967 * * * \\
(0.932)\end{array}$ & & & $\begin{array}{c}21.654^{* * *} \\
(4.789)\end{array}$ \\
\hline Client of PattiChiari & & $\begin{array}{c}0.272^{* * *} \\
(0.055)\end{array}$ & $\begin{array}{c}5.890^{* * *} \\
(1.070)\end{array}$ & \\
\hline $\mathrm{N}$ & 2714 & 2714 & 2714 & 2714 \\
\hline Ftest & & & & 24.608 \\
\hline
\end{tabular}


Table A-4: Association and Causal Effect of Financial Literacy on Financial Assets. 2010 subsamples.

\begin{tabular}{|c|c|c|c|c|}
\hline \multicolumn{5}{|c|}{ Households in which the household head is female } \\
\hline & OLS & FS & ITT & \multirow{3}{*}{$\begin{array}{c}\text { IV } \\
12.921^{* * *} \\
(2.590)\end{array}$} \\
\hline Fin. lit. (nb. correct/3) & $\begin{array}{c}3.338^{* * *} \\
(0.736)\end{array}$ & \multirow[b]{2}{*}{$0.348 * * *$} & \multirow[b]{2}{*}{$4.501^{* * *}$} & \\
\hline Client of PattiChiari & & & & \\
\hline $\mathrm{N}$ & 2208 & 2208 & 2208 & 2208 \\
\hline Ftest & & & & 40.878 \\
\hline \multicolumn{5}{|c|}{ Households in which the household head is male } \\
\hline & OLS & FS & ITT & IV \\
\hline Fin. lit. (nb. correct/3) & $\begin{array}{c}3.841^{* * *} \\
(0.775)\end{array}$ & & & $\begin{array}{c}20.009^{* * *} \\
(5.564)\end{array}$ \\
\hline Client of PattiChiari & & $\begin{array}{c}0.248^{* * *} \\
(0.050)\end{array}$ & $\begin{array}{c}4.965^{* * *} \\
(1.054)\end{array}$ & \\
\hline $\mathrm{N}$ & 2764.000 & 2764.000 & 2764.000 & 2764.000 \\
\hline Ftest & & & & 24.403 \\
\hline \multicolumn{5}{|c|}{ Households living in Northern Italy } \\
\hline & OLS & FS & ITT & IV \\
\hline Fin. lit. (nb. correct/3) & $\begin{array}{c}3.523^{* * *} \\
(1.203)\end{array}$ & & & $\begin{array}{c}20.166^{* * *} \\
(5.798)\end{array}$ \\
\hline Client of PattiChiari & & $\begin{array}{c}0.268^{* * *} \\
(0.073)\end{array}$ & $\begin{array}{c}5.395^{* * *} \\
(1.505)\end{array}$ & \\
\hline $\mathrm{N}$ & 2311 & 2311 & 2311 & 2311. \\
\hline Ftest & & & & 13.514 \\
\hline \multicolumn{5}{|c|}{ Households living in Central Italy } \\
\hline & OLS & FS & ITT & IV \\
\hline Fin. lit. (nb. correct/3) & $\begin{array}{c}4.865^{* * *} \\
(1.064)\end{array}$ & & & $\begin{array}{c}16.576^{* * *} \\
(4.197)\end{array}$ \\
\hline Client of PattiChiari & & $\begin{array}{c}0.326^{* * *} \\
(0.071)\end{array}$ & $\begin{array}{c}5.396^{* * *} \\
(1.266)\end{array}$ & \\
\hline $\mathrm{N}$ & 1094 & 1094 & 1094 & 1094 \\
\hline Ftest & & & & 20.939 \\
\hline \multicolumn{5}{|c|}{ Households living in Southern Italy } \\
\hline & OLS & FS & ITT & IV \\
\hline Fin. lit. (nb. correct/3) & $\begin{array}{c}2.930^{* * *} \\
(0.618)\end{array}$ & & & $\begin{array}{c}15.251^{* * *} \\
(4.581)\end{array}$ \\
\hline Client of PattiChiari & & $\begin{array}{c}0.265^{* * *} \\
(0.052)\end{array}$ & $\begin{array}{c}4.044^{* * *} \\
(1.003)\end{array}$ & \\
\hline & 1567 & 1567 & 1567 & 1567 \\
\hline Ftest & & & & 26.124 \\
\hline
\end{tabular}


Table A-5: Association and Causal Effect of Financial Literacy on Financial Assets. 2010 subsamples.

\begin{tabular}{|c|c|c|c|c|}
\hline \multicolumn{5}{|c|}{ Households not working in agriculture } \\
\hline & OLS & FS & ITT & IV \\
\hline Fin. lit. (nb. correct/3) & $\begin{array}{c}3.410^{* * *} \\
(0.689)\end{array}$ & & & $\begin{array}{c}16.015^{* * *} \\
(2.721)\end{array}$ \\
\hline Client of PattiChiari & & $\begin{array}{c}0.295^{* * *} \\
(0.039)\end{array}$ & $\begin{array}{c}4.723^{* * *} \\
(0.792)\end{array}$ & \\
\hline $\mathrm{N}$ & 4677 & 4677 & 4677 & 4677 \\
\hline Ftest & & & 26.124 & 56.605 \\
\hline \multicolumn{5}{|c|}{ Households not working in financial sector } \\
\hline & OLS & FS & ITT & IV \\
\hline Fin. lit. (nb. correct/3) & $\begin{array}{c}3.413^{* * *} \\
(0.677)\end{array}$ & & & $\begin{array}{c}16.239 * * * \\
(2.707)\end{array}$ \\
\hline Client of PattiChiari & & $\begin{array}{c}0.285^{* * *} \\
(0.039)\end{array}$ & $\begin{array}{c}4.623^{* * *} \\
(0.763)\end{array}$ & \\
\hline $\mathrm{N}$ & 4710 & 4710 & 4710 & 4710 \\
\hline Ftest & & & & 52.920 \\
\hline
\end{tabular}

Table A-6: Unconfoundedness of PattiChiari Status with Respect to Credit Services Probit Regression Results (Coefficients and Standard Errors in Parentheses)

\begin{tabular}{lllll}
\hline \hline & $\begin{array}{l}\text { Prob. of being } \\
\text { Liq. Constrained }\end{array}$ & $\begin{array}{l}\text { Prob. of having } \\
\text { a fixed rate mortg. }\end{array}$ & $\begin{array}{l}\text { Level of } \\
\text { fixed int.rate }\end{array}$ & $\begin{array}{l}\text { Level of } \\
\text { adj. int.rate }\end{array}$ \\
\hline Client of PattiChiari & -0.135 & -0.150 & -0.573 & 0.433 \\
& $(0.094)$ & $(0.288)$ & $(0.764)$ & $(1.189)$ \\
Age & 0.027 & 0.071 & 0.198 & 0.124 \\
Age sq. & $(0.021)$ & $(0.054)$ & $(0.231)$ & $(0.087)$ \\
& $-0.000^{* * *}$ & -0.001 & -0.002 & -0.001 \\
Male & $(0.000)$ & $(0.001)$ & $(0.002)$ & $(0.001)$ \\
& $0.131^{*}$ & -0.099 & -0.515 & -0.133 \\
Married & $(0.075)$ & $(0.179)$ & $(0.567)$ & $(0.833)$ \\
& $-0.404^{* * *}$ & 0.048 & -0.445 & 0.157 \\
Nb. hh components & $(0.110)$ & $(0.265)$ & $(0.627)$ & $(0.672)$ \\
& $0.110^{* *}$ & 0.001 & 0.212 & -0.149 \\
Municip. 20.000-40.000 inh. & $(0.043)$ & $(0.101)$ & $(0.175)$ & $(0.354)$ \\
& 0.041 & -0.068 & $-0.880^{*}$ & -0.766 \\
Municip. 40.000-500.000 inh. & $(0.160)$ & $(0.233)$ & $(0.519)$ & $(1.015)$ \\
Municip. 500.000+ inh. & $(0.011$ & -0.145 & -0.739 & -1.037 \\
& $-0.144)$ & $(0.234)$ & $(0.634)$ & $(0.929)$ \\
\hline $\mathrm{N}$ & $(0.291)$ & $-0.414^{* *}$ & -0.104 & -1.507 \\
\hline \hline
\end{tabular}

Notes: ${ }^{*} p<0.1,{ }^{* *} p<0.05,{ }^{* * *} p<0.01$. All regressions include a constant, and province dummies.

Errors robust to heteroskedasticity and clustered at the province level in parentheses; marginal effect in squared brackets. 


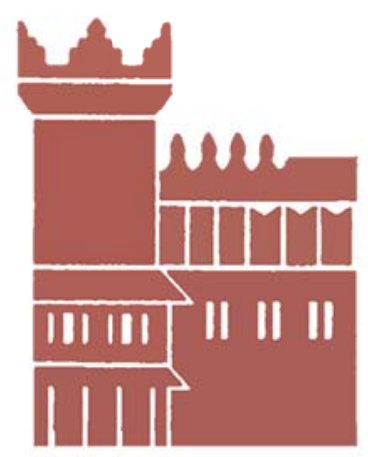

Alma Mater Studiorum - Università di Bologna DEPARTMENT OF ECONOMICS

Strada Maggiore 45

40125 Bologna - Italy

Tel. +39051 2092604

Fax +390512092664

http://www.dse.unibo.it 